\title{
A century of advances in bumblebee domestication and the economic and environmental aspects of its commercialization for pollination*
}

\author{
Hayo H.W. VelTHUIS ${ }^{\mathrm{a}}$, Adriaan van DoORN ${ }^{\mathrm{b}}$ \\ ${ }^{a}$ Klemit 1, 5325 KG Wellseind, The Netherlands \\ ${ }^{\mathrm{b}}$ BumbleConsult, Rodenrijseweg 529, 2651 AR Berkel en Rodenrijs, The Netherlands
}

Received 2 May 2005 - revised 1 November 2005 - accepted 8 November 2005

\begin{abstract}
This paper reviews a century of progress in techniques of bumblebee rearing, starting with those used to encourage bumblebee queens to initiate a colony in artificial domiciles and including those needed for the commercial production of large numbers of colonies for the pollination of agricultural crops. Five species of bumblebees are currently used for crop pollination, the major ones being Bombus terrestris from Eurasia and Bombus impatiens from North America. As a result of their frequent use in foreign territories, there have been reports of $B$. terrestris becoming established, as well as interactions and/or competition with local (bumble-) bee fauna. Of the many vegetable, fruit and seed crops that bumblebees pollinate, greenhouse tomatoes are of predominant importance. In 2004, 40000 ha of tomato crops were pollinated, with a crop value of $€ 12000$ million. The growers benefit from bumblebee pollination because of lower production costs, increased yields, and improved fruit quality. The interrelationship between commercial mechanisms and ecological risks is discussed.
\end{abstract}

bumblebee / pollination / commercial rearing / economic value / ecological impact

\section{INTRODUCTION}

Discussions on sustainable development generally agree that nature still harbors large numbers of organisms that are potentially and directly important to mankind. Their profitable use is just awaiting the discovery of their value or the formulation of how they should be propagated. With regard to the more than 20000 species of bees (Michener, 2000), it has been recognized that all but the parasitic ones play a role in pollination, leading to the production of seeds and fruits, and that the various morphological differences between the species (e.g., body size and the absolute and relative tongue length) are related to a certain degree of specialization for the various flower types.

Corresponding author: H.H.W. Velthuis, hhwv@xs4all.nl

* Manuscript editor: Jean-Noël Tasei
Although the potentials of the different bee species have been recognized by several researchers (e.g., Free, 1970, 1993; Parker et al., 1987; Cane, 1997), the diversity of the species has not yet played an important role in the design of agricultural systems. For example, when the pollination by 'wild' bees is satisfactory, economic prospects will stimulate farmers to increase the planted area. This will, however, lead to diminished effectiveness (e.g. Kremen et al., 2002). To remedy this, more bees will have to be brought in from elsewhere or the local nesting success will have to be stimulated by providing nesting material and alternative food sources. Such pollination schemes are usually limited to relatively small geographic regions. To date, there are three species of solitary bees that are produced on a commercial basis to provide this kind of pollination service: Nomia melanderi, used in the 
U.S. and New Zealand for alfalfa pollination, Megachile rotundata, used in several countries also for alfalfa; and Osmia cornifrons, used in Japan and the eastern U.S. for apples and almonds (reviewed by Bohart, 1972; Torchio, 1987; Maeta, 1990). A relatively new candidate for commercial rearing is Osmia lignaria, which is used in North America for a number of fruit crops, notably almonds and apples (Torchio, 1987; Bosch and Kemp, 2001).

The potential value of bumblebees as pollinating insects in agriculture has been recognized for a long time. Because their tongues are longer than those of honeybees, bumblebees are much better at pollinating flowers with deep corollas (Hobbs et al., 1961; Holm, 1966a). Because of this, hundreds of bumblebee queens, caught in the U.K., were deliberately introduced into New Zealand in 1885 and 1906, to improve seed set of red clover. Four of the species (Bombus hortorum, B. ruderatus, $B$. subterraneus and B. terrestris) became established (Hopkins, 1914). In 1982 and 1983, $B$. ruderatus was brought from New Zealand to Chile for the pollination of red clover. This species established itself there as well (Arretz and MacFarlane, 1986). The potential of bumblebees for crop pollination has been emphasized repeatedly (e.g., Medler, 1957; Holm, 1966a; Free, 1970, 1993; Pouvreau, 1984; Plowright and Laverty, 1987). The same authors also stressed that the exploitation of these potentials should be based not only on propagation of natural populations (for instance, through habitat improvement or the introduction of artificial nesting boxes), but also on domestication.

Domestication attempts have a long history. Sladen, for example, addressed this subject in 1912 in Chapter VII of his famous book The humble-bee. He noted some problems, like mating and hibernation, but was convinced that they could be overcome. Since Sladen's publication, a large number of researchers has contributed bits and pieces to the process of domestication, i.e. controlling every step of the bumblebee's life cycle, but it was not until the 1970s that domestication became a fact (e.g. Röseler, 1977). As soon as bumblebees were domesticated, discussions on the possibilities for commercial rearing began (e.g.,
Röseler, 1979; Plowright and Laverty, 1987). In 1987 commercial rearing finally started. Now, 18 years after the start of commercial rearing, almost one million colonies (mainly $B$. terrestris and $B$. impatiens) are produced annually.

This paper describes (1) the history of bumblebee research related to domestication, (2) the current practice of commercial bumblebee rearing, (3) the crops commercially pollinated by bumblebees and their economic value, and last but not least (4) the environmental concerns related to the commercial application of bumblebees all over the world.

\section{HISTORY OF BUMBLEBEE RESEARCH RELATED TO DOMESTICATION}

Since Sladen's research (1912), a large number of interested naturalists as well as professional biologists, mainly in Europe and North America, have studied bumblebees and published their results. These researchers lured spring queens to artificial domiciles and/or collected queens in the field and got them established in nest boxes or observation hives (e.g., Jordan, 1936; Hasselrot, 1952, 1960; Fye and Medler, 1954). While working with field collected queens of European species, they also discovered that colony initiation improved when the queens are first imprisoned for some time and/or provided with honey and pollen inside the nest boxes. Sladen (1912) observed that placing queens in pairs led to aggressive behavior and subsequently to one of the queens starting to breed. He also attained this stimulation effect using conspecific workers or workers of a closely related species, e.g., workers of B. lucorum stimulated queens of $B$. terrestris. Both species belong to the subgenus Bombus s.s. Latreille (Richards, 1968; Williams, 1998). Sladen (1912) also succeeded in getting young queens of $B$. lapidarius to mate. Frison (1927) achieved the same results with the North American species $B$. americanorum, $B$. bimaculatus and $B$. vagans. In addition, Frison (1927) succeeded in hibernating $B$. americanorum queens in jars containing loose soil and old leaves, buried in 
the ground outdoors. He did not, however, try to get these hibernated queens established in his own nest boxes. During this period, i.e. the first half of the 20th century, all domestication attempts were similar in that, after colony initiation, the colonies were left unattended in the field, i.e. the bees collected their own food nearby from a variety of natural vegetation or from seed crops.

Early in the second half of the 20th century, a number of researchers focused on improving colony initiation. Cages or greenhouses were supplied with suitable food plants and nest boxes. Field-collected queens, just emerged from hibernation, were released in these environments. A number of these queens accepted the conditions and started to breed. After colony establishment, the nest boxes were brought to the field.

Another problem was how to obtain hibernating queens. A good method was to place mature colonies inside the cages or greenhouses, together with trays filled with earth or peat. The colonies produced both males and queens, and after mating the queens used the loose material in the trays to dig in (Hobbs et al., 1960, 1962; Hobbs, 1967a; Holm, 1960, 1966b; Zapletal, 1961; Pouvreau, 1965, 1970; Bornus, 1975; Bilinski, 1976, 1977, 2000). Hobbs worked with the American species $B$. rufocinctus, B. huntii, B. occidentalis, $B$. fervidus and B. appositus, while the European researchers studied mainly $B$. terrestris and B. lapidarius, but also B. agrorum (= pascuorum), B. hortorum, B. hypnorum, B. pratorum and $B$. ruderarius. This approach was reasonably successful in that a varying number of bumblebee colonies could be established for the pollination of field crops that flowered in spring. It did not, however, lead to complete domestication.

At the same time, other researchers (notably Plowright, Röseler and Pomeroy), working on different aspects of bumblebee biology (behavior, physiology, ecology), tried to develop a system for rearing bumblebees in total confinement. Their aim was to become independent from the bumblebees' seasonal life cycle, and to have material available for observations or experiments at any time of the year. The Swiss researcher Horber (1961) was the first to publish a report on a continuous rearing system for bumblebees. He discovered that queens of $B$. hypnorum, after mating, could be induced to start a colony by bringing them into a rearing room with artificial illumination and raising the temperature in that room (he used a temperature varying between 30 and $35.5^{\circ} \mathrm{C}$ ). Horber also successfully applied this technique to queens that had hibernated for a short time. This last strategy was adopted by Plowright and Jay (1966), working with queens of the North American B. rufocinctus (after a 4-week hibernation period) and Röseler (1977), working with the European species B. terrestris and B. hypnorum (minimum hibernation period of 6 weeks). Since Horber's 1961 publication, a number of continuous rearing systems have been set up in several countries for research purposes and new discoveries have led to the improvement of the techniques. The most important aspects are discussed below.

\subsection{Climate in the rearing room}

Horber's (1961) rearing temperature of at least $30{ }^{\circ} \mathrm{C}$ was soon lowered down to 28 $30{ }^{\circ} \mathrm{C}$ by both Plowright and Jay (1966) and Röseler (1977). These latter researchers also noticed that relative humidity $(\mathrm{RH})$ should not be below $50 \%$. This was confirmed by Yoon et al. (2002), who, working with the Asian species B. ignitus, compared three temperature regimen $\left(23,27\right.$ and $\left.30^{\circ} \mathrm{C}\right)$ and three $\mathrm{RH}$ regimen $(50,65$ and $80 \%$ ), and obtained the best results at $27{ }^{\circ} \mathrm{C}$ and $65 \% \mathrm{RH}$. Pomeroy and Plowright (1980) as well as Katayama (1989) adapted the electrically heated observation boxes developed by Sakagami (1966) for their bumblebee studies.

\subsection{Storage of hibernating queens}

Horber (1961) stored his mated B. hypnorum queens separately in small aluminum tubes containing damp vermiculite at $1{ }^{\circ} \mathrm{C}$ in a refrigerator and obtained as much as $87 \%$ survival after a 9-month hibernation period. Others tried different containers and used different 
materials to keep the RH high. Zapletal (1961) and von Hagen (1986), for example, used small clay containers or matchboxes filled with damp peat for the hibernating queens of a number of European species; Milliron (1967) used small jars filled with damp, decayed wood for the hibernating queens of the North American species B. fervidus; and Röseler (1977) used small boxes filled with moist paper pulp or peat mixed with vermiculite. All of these researchers stored their queens at a temperature between 1 and $4{ }^{\circ} \mathrm{C}$. Horber (1961) also used a refrigerator temperature of $-1{ }^{\circ} \mathrm{C}$ and found a lower survival rate (only $53 \%$ compared to $87 \%$ at $+1{ }^{\circ} \mathrm{C}$ ). Later, Beekman et al. (1998) compared above and below freezing temperatures for hibernation (i.e., $+15,10,5,0$ and $-5{ }^{\circ} \mathrm{C}$ ) and found that a temperature of $+5^{\circ} \mathrm{C}$ gave the best results. Later, Beekman et al. (1999) tried to establish a diapause-free line of $B$. terrestris, but were unsuccessful.

Other researchers (Plowright and Jay, 1966; Duchateau, 1985) stuck to the hibernation methods resembling the method used by Holm (1960) and Pouvreau (1970), among others. Briefly, the mated queens were allowed to dig into a heap of soil, peat or moss in the mating cage. Then, either the tray with the queens was transferred to a cool room or the queens were dug out of the heap and either singly or in a group put into containers that were then stored in a refrigerator.

\subsection{Circumventing or breaking diapause}

Horber's method (1961) of inducing queens to initiate a colony after no or only a short hibernation period (by raising both the room temperature and the light intensity) was soon adopted by other researchers (Plowright and Jay, 1966; Röseler, 1977). In 1985 Röseler published that a $\mathrm{CO}_{2}$-treatment could also be used to circumvent or break diapause. This proved to be an easier method and, later, became a key instrument in the commercial production of bumblebee colonies.

\subsection{Colony initiation}

As mentioned before, Sladen (1912) discovered that colony initiation could be stimulated by placing two queens together. The two-queen method was successfully adopted by a number of researchers (e.g., Plowright and Jay, 1966; Alford, 1975; Duchateau, 1985; Hannan et al., 1997). The method works quite well; however, the resulting aggressiveness often leads to the death of one of the two queens and thus to a loss of queens. Other methods used by Sladen (1912) were to put a queen together with some conspecific workers or with a cluster of cocoons from another colony. Both of these methods were also applied by Alford (1975). Since the availability of brood is often limited, isolated cocoons, usually of males, were also tried (see, e.g., Duchateau et al., 1994). There are a number of features that may attract queens to these cocoons, including the odor (Heinrich, 1974; Gamboa et al., 1987) and/or the slightly higher temperature (up to $2{ }^{\circ} \mathrm{C}$ higher than the ambient temperature in the nest as a result of the queen's own metabolism; see, e.g., Barrow and Pickard, 1985; Cameron, 1985). Kwon et al. (2003a) found that young cocoons (less than two days old) give the highest rate of colony initiation and that horizontally placed cocoons enable the queen to build more egg cups on top of them and thus speed up colony development. Others introduced both a fresh male cocoon and some conspecific bumblebee workers into the nest box with the queen and achieved the same results (see, e.g., van Doorn and Heringa, 1986). Ono et al. (1994) used workers of $B$. terrestris to stimulate the queens of the closely related $B$. hypocrita. Similarly, $B$. terrestris workers were used to stimulate colony initiation of the closely related $B$. ignitus (van Doorn, unpubl.). Ptacek $(1985,1991)$ developed a system using honeybee workers instead of bumblebee workers; each queen was joined by 3 to 7 callow honeybee workers. He obtained good results with this method when working with queens of $B$. terrestris, but not with queens of other species (B. lapidarius, B. lucorum, B. hypnorum, B. pratorum, $B$. agrorum, B. hortorum and B. ruderatus). This latter method was adopted by others (e.g., 
van Heemert et al., 1990; van den Eijnde et al., 1991). However, during the winter period, callow worker honeybees are often difficult to obtain (Ptacek, 2001).

The above-mentioned methods for stimulating and improving colony initiation were compared by Gretenkord and Drescher (1997). They obtained better results using bumblebees (i.e., either a second queen, a worker, a cluster of brood, or a combination of brood and a worker) than using honeybee workers. Ptacek (2001) also compared the different methods and confirmed that bumblebees were more inciting than honeybees. Tasei and Aupinel (1994) tested different photoperiodic regimen and found that, for colony initiation, a daily light period of eight hours gave the best results.

\subsection{Mating}

Most B. terrestris queens become receptive at 6 days of age (range 1-11 days; Duchateau, 1985; Tasei et al., 1998; Ptacek, 2000), whereas most males begin responding to queens at about 10 days of age (mating range 5-25 days; Duchateau, 1985; Duchateau and Mariën, 1995; Tasei et al., 1998). To obtain inseminated queens, males and queens of the appropriate ages are placed in mating cages of $40 \times 40 \times 60 \mathrm{~cm}$ in size or any bigger. Mating takes place mainly during the morning hours; sunlight or bright illumination promotes success (Duchateau, 1985; Ptacek, 2000).

Mating usually lasts at least half an hour in $B$. terrestris and a number of other species (Röseler, 1973; van Honk et al., 1978; Duvoisin et al., 1999; Ptacek, 2001; Brown et al., 2002) and on average 23 minutes (range 10-38 min) in the Asian species B. ignitus (Yoon et al., 1999). It has been reported to be much shorter in some North American species (B. rufocinctus and B. frigidus; Foster, 1992). A long mating duration means that the mating cages only have to be checked once every 15 minutes instead of continuously.

So far, queens of almost all investigated European species mate only once (Röseler, 1973; Estoup et al., 1995; Schmid-Hempel and Schmid-Hempel, 2000); a well-known exception is B. hypnorum (Pouvreau, 1963;
Röseler, 1973; Estoup et al., 1995; SchmidHempel and Schmid-Hempel, 2000; Paxton et al., 2001; Brown et al., 2002). Multiple mating of queens has been found to occur more frequently among the North American species (Hobbs, 1967b; Foster, 1992, and discussed in Schmid-Hempel and Schmid-Hempel, 2000). Effective mating efficiency in B. hypnorum can be as high as 3.13 , but is usually close to one (Schmid-Hempel and Schmid-Hempel, 2000; Paxton et al., 2001). Queens of monandrous species in captivity have been occasionally observed to mate more than once (Röseler, 1973; Duvoisin et al., 1999, and van Doorn, unpubl., for B. terrestris; Cnaani et al., 2002, for B. impatiens). Males, on the other hand, may copulate several times (Röseler, 1973; Foster, 1992; Tasei et al., 1998). Röseler (1973) found a decrease in the number of transferred sperms after the second copulation, while Tasei et al. (1998) found equal numbers up to the third mating. This reduced transfer of sperm, however, does not affect the productivity of the queens (Röseler, 1973).

In the mating cages the percentage of mated queens has been reported to be around $75 \%$ for B. terrestris $(80 \%$ by Duchateau, 1985; $74 \%$ by Gretenkord and Drescher, 1997; 69\% by Tasei et al., 1998). B. terrestris and B. hypnorum males have also been found to transfer a mating plug during mating (Duvoisin et al., 1999; Baer et al., 2001; Brown et al., 2002). Recently, artificial insemination became possible (Baer and Schmid-Hempel, 2000).

\subsection{Pollen}

Honeybee-collected pollen is usually used to rear bumblebee colonies indoors. Plowright and Jay (1966) and Röseler (1977) noticed that, to obtain good rearing results, the pollen should be freshly frozen (as opposed to dried) and that the pollen patty, or pollen lump, should be replaced daily or at least every other day. Maurizio (1958) already discussed the degrading effects of several methods for conserving pollen. Ribeiro et al. (1996) and Ptacek (2001) confirmed this in their studies comparing fresh and dried pollen. Not only the physical, but also the chemical properties play a 
role. The food components in pollen differ according to plant species, leading to different survival rates in honeybees when fed only one type of pollen. Similarly, when pollen quality was tested for bumblebees, it was found that rearing success is better with pollen containing a high protein content (e.g., from Brassica and Prunus) than with pollen from other plants species (e.g., Helianthus and Taraxacum). The cause of the lower rearing success could, however, be caused by a deficiency in components such as an essential amino acid or vitamin instead of a low protein content that characterizes some insect-pollinated and many windpollinated plants (Stanley and Linskens, 1974; Schmidt et al., 1987; Day et al., 1990; Regali and Rasmont, 1995; Roulston and Cane, 2000; Aupinel et al., 2001; Génissel et al., 2002). Corn (Zea mays) pollen, a wind-pollinated species, has been found to have a low nutritional value (van Doorn, unpubl.). This has also been described for another windpollinated species, Typha latifolia (Schmidt et al., 1989). Bumblebee colonies that forage in the greenhouse on tomato plants develop normally (van Doorn, unpubl.; Whittington and Winston, 2003a).

\section{COMMERCIAL BUMBLEBEE REARING}

\subsection{Initial attempts in commercial rearing}

The many attempts to stimulate the establishment and growth of bumblebee colonies in or near agricultural field plots are indicative of the hope researchers had concerning the applicability of these bees. There was also pessimism, however, concerning the economic feasibility of rearing these insects for the purpose of pollination (Free, 1970; Röseler, 1979). The relatively high labor costs and the often low success rate were considered major barriers for economic success. It seemed that these costs could only be compensated for by high-value crops, e.g., those for hybrid seed production, especially if they needed hand pollination. These were the crops that were considered potentially good targets for research (e.g., Minderhoud, 1950; Sneep, 1952; Kraai, 1958; Velthuis and Cobb, 1991).

In 1985, the Belgian veterinarian and amateur bumblebee researcher Dr. de Jonghe quite unexpectedly discovered the value of bumblebees (B. terrestris) for the pollination of greenhouse tomatoes (van Ravestijn and Nederpel, 1988). Until then, tomato flowers in Belgian and Dutch greenhouses had been pollinated mechanically by vibrating the plants three times a week. The labor involved in this process exceeded $€ 10000$ per ha per year (van Ravestijn and Nederpel, 1988). In other countries, tomato flowers in caged crops were either pollinated in the same way or treated with hormones with a comparable frequency. In 1987, Dr. de Jonghe founded the company Biobest for the commercial rearing of bumblebees. His initiative was followed in the next year by the Dutch company Koppert Biological Systems, a producer of biological control agents since 1967, and in 1989 by another Dutch company, BBB (Bunting Brinkman Bees). Since then, many more producers started rearing bumblebees, although only a few have ultimately survived the competitive market. There are over 30 producers worldwide today (Tab. I); still most of the market share is covered by the 3 companies mentioned above. The bigger companies have rearing facilities not only in their homeland, but also in other countries and on other continents, usually under their own name. There, they mainly, or exclusively, rear colonies for the local market using native species.

One year after the start of the production, Biobest was able to supply bumblebee colonies to some 40 hectares of tomato crop (van Ravenstijn and Nederpel, 1988). The rapid increase in the use of commercially reared bumblebees for the pollination of tomato crops (as illustrated in Fig. 1 for The Netherlands) was facilitated by a number of factors:

1. Even in the early days, bumblebee pollination was cheaper than mechanical pollination $[€ 9100$ per ha per year in The Netherlands and Belgium (van den Bogaard, 1991) compared to $€ 10000$ per ha per year (van Ravestijn and Nederpel, 1988)]. 
Table I. List of countries with production facilities for bumblebee rearing and the names of the companies involved. The list also includes the names of the reared Bombus species. Note that Bombus terrestris is divided into a number of subspecies (Krüger, 1958; Rasmont et al., unpubl. data). In those cases where B. terrestris has been listed, it usually concerns the subspecies $B$. t. dalmatinus. The information to confirm this, however, is missing. Only when there is absolutely no doubt has the subspecies level been mentioned.

\begin{tabular}{|c|c|c|}
\hline $\begin{array}{l}\text { COUNTRIES } \\
\text { (per continent) }\end{array}$ & COMPANIES & (sub-)SPECIES REARED \\
\hline \multicolumn{3}{|l|}{ Europe } \\
\hline$\overline{\text { Belgium }}$ & Biobest, BIP & $\begin{array}{l}\text { B. terrestris (including B.t. canariensis } \\
\text { for the Canary Islands and } \\
\text { B. t. sassaricus for Sardinia), } \\
\text { B. ignitus (for Japan) }\end{array}$ \\
\hline France & GTICO, GIE Lacroix & B. terrestris \\
\hline Germany & STB-Biocontrol & B. terrestris \\
\hline Italy & Agriapi & B. terrestris \\
\hline The Netherlands & $\begin{array}{l}\text { Bunting Brinkman Bees (BBB), } \\
\text { Biopol, Koppert }\end{array}$ & B. terrestris \\
\hline Norway & $\begin{array}{l}\text { Bombus Pollinering, Norbol, } \\
\text { Pollinering Service }\end{array}$ & B. terrestris terrestris \\
\hline Russia & 5 small companies & B. terrestris \\
\hline Slovakia & Koppert & $\begin{array}{l}\text { B. terrestris (including B. t. canariensis } \\
\text { for the Canary Islands), } \\
\text { B. ignitus (for Japan) }\end{array}$ \\
\hline Spain & Agrobio & B. terrestris \\
\hline \multicolumn{3}{|l|}{ Asia } \\
\hline$\overline{\text { Israel }}$ & Bio-Bee, Yad Mordechai & B. terrestris dalmatinus \\
\hline Japan & Api Company, Cats Agrisystems & B. terrestris \\
\hline Korea & $\begin{array}{l}\text { Sesil Corporation, } \\
\text { Yae-cheon Industry, Mr. Lee }\end{array}$ & B. terrestris \\
\hline Turkey & BBB, Biobest, Koppert & B. terrestris dalmatinus \\
\hline China & $\begin{array}{l}\text { Beijng Yong-An-Xin Biological } \\
\text { Pollination Company }\end{array}$ & B. lucorum, B. ignitus, B. terrestris \\
\hline \multicolumn{3}{|l|}{$\underline{\text { North America }}$} \\
\hline$\overline{\text { Canada }}$ & $\begin{array}{l}\text { Apipol, Biobest, Global } \\
\text { Horticulture, Groupe } \\
\text { Horticole Ledoux }\end{array}$ & B. impatiens, B. occidentalis \\
\hline Mexico & Koppert & B. impatiens \\
\hline United States & Koppert & B. impatiens \\
\hline \multicolumn{3}{|l|}{ South America } \\
\hline$\overline{\text { Chile }}$ & Bio Control, Ipanema & B. terrestris \\
\hline \multicolumn{3}{|l|}{$\underline{\text { Africa }}$} \\
\hline \multicolumn{3}{|l|}{ Australasia } \\
\hline New Zealand & Zonda, Biobees & B. terrestris audax \\
\hline
\end{tabular}




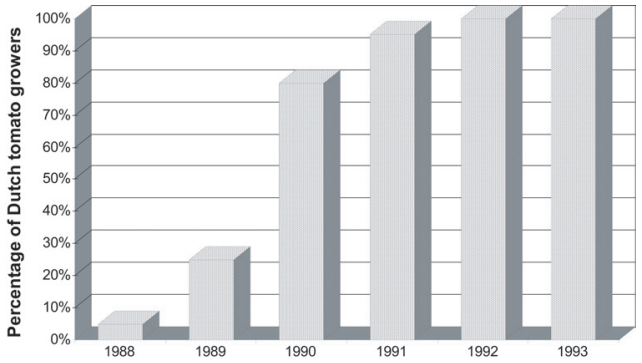

Figure 1. Application of bumblebees for pollination by Dutch tomato growers since the start of commercial rearing in 1987.

2. The degree of bumblebee flower visitation can be easily monitored by farmers. Tomato flowers, which are highly self-fertile, need to be shaken to release their pollen. In nature, this is done perfectly by so-called buzz-pollinators like bumblebees (Buchmann, 1983). When bumblebees visit a flower, they grasp the anther cone with their mandibles and leave visible brown bite marks on the yellow flowers (van den Bogaard, 1991; van Ravestijn and van der Sande, 1991; Morandin et al., 2001a, b).

3. Bumblebee pollination leads to higher fruit quality and increased total yield, and thus to a better price (The Netherlands: van der Sande, 1990; van Ravestijn and van der Sande, 1991; U.K.: Banda and Paxton, 1991; Poland: Orlowski and Grzeszczuk, 2003; Spain: Molina Herrera and Garcia Espinosa, 1992; Italy: Fiume and Parisi, 1994; Vecchio et al., 1996; Turkey: Abak et al., 1995; Dasgan et al., 2004; Israel: Presman et al., 1999; Japan: Wada, 1993; Korea: Lee et al., 1998; Canada: Kevan et al., 1991; Straver and Plowright, 1991; Dogterom et al., 1998). Bumblebees visit the flowers when they are physiologically best prepared: i.e., the flower may emit a scent that helps the bumblebees identify which is ready for pollination. When mechanical pollination was performed in the past, the flowers were often not treated at the proper moment.

4. Alternatives for chemical pesticide control became available already earlier. By 1987 , many Belgian and Dutch tomato growers had already become very restrictive in the use of chemicals for crop protection. Instead of pes- ticides, they were using the parasitic wasp Encarsia formosa to fight their main pest, the whitefly Trialeurodes vaporariorum (van Lenteren and Woets, 1988). Thus, the development of the bumblebee colonies in these greenhouses was not hampered by the use of harmful chemicals. Quite rapidly, the wish to use bumblebees and to increase the lifetime of the colonies, caused other tomato growers to become restrictive in their use of chemicals. This development first occurred in Western Europe, but was quickly seen in Southern Europe and other parts of the world. It is safe to say, therefore, that the use of bumblebees for pollination has caused a strong reduction in the use of pesticides in tomato crops, among others, and has thus made the products safer and the environment cleaner.

The chronology of the worldwide expansion of the use of commercially reared bumblebees for pollination is shown in Table II.

\subsection{Principles of the commercial rearing process}

In order to set up a bumblebee-rearing process, queens, preferably those which have just emerged from their hibernation sites, must be collected from natural populations. Tens of thousands of queens were collected in the early years. With increasing insight into the colony developmental processes, however, the major bumblebee producers were soon able to rely completely on their own production. To reach this, a small proportion of the produced colonies is set apart for the production of queens and males.

All bumblebee producers today have developed their own rearing systems, which are kept primarily secret. As a result, we only present a general outline of the commercial rearing process. The process was first outlined by Hughes in 1996. Every week, young hibernated queens are taken from the stock; the number depends on the production plan that is related to the sales forecast (i.e., concerning the sales about 8 weeks later). The length of the hibernation period of the used queens is variable in order to cope with peaks in sales. The queens may receive $\mathrm{CO}_{2}$ narcosis. They are then installed 
Table II. Timetable showing the worldwide expansion of the bumblebee market. Commercial use started in Europe in 1987. The position of a country's name corresponds with the first year that bumblebees were commercially used there for tomato pollination.

\begin{tabular}{|c|c|c|c|c|c|c|}
\hline & Europe & North America & Australasia & Asia & Africa & South America \\
\hline 1987 & Belgium & & & & & \\
\hline 1988 & The Netherlands & & & & & \\
\hline 1989 & France, UK & & & & & \\
\hline 1990 & & Canada & & & & \\
\hline 1991 & & USA & New Zealand & Israel & & \\
\hline 1992 & Spain, Italy & & & Japan & & \\
\hline 1993 & & & & & Morocco & \\
\hline 1994 & & Mexico & & & & \\
\hline 1995 & & & & Korea & & \\
\hline \multicolumn{7}{|l|}{1996} \\
\hline 1997 & & & & Turkey & & \\
\hline 1998 & & & & & & Chile \\
\hline \multicolumn{7}{|l|}{1999} \\
\hline 2000 & & & & China & & \\
\hline \multicolumn{7}{|l|}{2001} \\
\hline \multicolumn{7}{|l|}{2002} \\
\hline \multicolumn{7}{|l|}{2003} \\
\hline \multicolumn{7}{|l|}{2004} \\
\hline 2005 & & & & & & \\
\hline
\end{tabular}

in small starter boxes in a climate room $\left(28^{\circ} \mathrm{C}\right.$ or lower, depending on the system; $\mathrm{RH}$ around $60 \%$ ). In the rearing industry, different methods are used to stimulate colony initiation. They include the use of bumblebee or honeybee workers, whether or not in combination with male cocoons or artificial cocoons. Artificial cocoons are molded out of Styrofoam or plastic and they may be used in combination with a heating device to raise their temperature (using a hot water system, light bulbs or electric heating). As soon as or somewhat after the first workers have emerged, the colonies are transferred to a larger nest box (usually a clickin system). This enables full colony development once the nest box is in the greenhouse. The colonies are fed sugar syrup (approx. 50\% sugar content, w/w) and pollen (bought from beekeepers) while in the rearing facilities. The syrup contains a preservative and the sugar composition is balanced to prevent crystallization (see also Ptacek, 2001). It is estimated that approximately one million $\mathrm{kg}$ of sugar syrup are used by all of the bumblebee rearing facilities and that another two million $\mathrm{kg}$ of sugar syrup (approx. 65\%,w/w) are used annually to feed all of the colonies used in the greenhouses. Finally, more than 200 tons of honeybee-collected pollen are used annually by all bumblebee producers worldwide.

Colonies meant for sale are typically selected when they have reached a size of around 50 workers. The nest box usually consists of a plastic inner box and a cardboard outer box. The bees have access to a supply of sugar solution underneath the inner box: usually around 2 liters of the syrup are provided. This amount is needed because the flowers of the main target crop, tomatoes, do not produce nectar. Moreover, it is sufficient for the entire lifespan of the colony in the greenhouse, which is typically between 8 and 12 weeks. The worker population of a colony in a greenhouse typically increases to a peak of around 200 live 
individuals about three to five weeks after introduction. The colony then starts producing hundreds of males (and some queens as well).

As mentioned before, a small proportion of the colonies is set apart for the production of sexuals (queens and males). By monitoring these colonies, a parasite-free queen stock can be built up. Under natural circumstances, a bumblebee nest may contain several commensals and parasitic organisms (Skou et al., 1963; Pouvreau, 1973, 1974; Alford, 1975; MacFarlane et al., 1995; Goulson, 2003a). Unless entire colonies are taken from the field, commensals rarely gain entrance to rearing facilities. Exceptions are phoretic commensals like the mites Parasitellus (Parasitus) fucorum and Kuzinia laevis, which may be present on the bodies of field-caught queens. These mites are not, however, able to survive in the artificial rearing environments. Fieldcaught queens may also carry internal parasites. Two that can cause major problems in bumblebee rearing facilities are the protozoan Nosema bombi and the tracheal mite Locustacarus (Bombacarus) buchneri (Skou et al., 1963; MacFarlane et al., 1995; van den Eijnde, 2000; van der Steen, 2000). Since there are as yet no effective agents against these parasites (see Whittington and Winston, 2003b, for Nosema bombi), the only alternative is to destroy all infested colonies. Since the brood parasites Melittobia acasta (MacFarlane and Donovan, 1989; de Wael et al., 1993) and M. chalybii (Whitfield and Cameron, 1993) can also cause severe damage, precautions must be taken to keep these hymenopteran parasitoids out of the rearing facilities. Again, if an infection occurs, the only solution is to destroy all infested colonies. Less devastating, but still an ongoing problem for the rearing industry, are the pest species that feed on stored food, e.g., the pyralid moths Vitula edmandsii (Whitfield and Cameron, 1993) and Plodia interpunctella (de Ruijter et al., 1997; Kwon et al., 2003b). The larvae of these two species feed primarily on pollen, but occasionally also on bumblebee brood. Moreover, their presence acts as a repellent to adult bumblebees. Their numbers can be kept under control by means of pheromone lures and sanitary measures. Spraying the colony with the microbial insect pathogen Bacillus thuringiensis Aizawai can also control the pest larvae (99.8\% mortality) without harming the bumblebees (Kwon et al., 2003b).

A parasite-free status is not only important for the rearing, but also for exporting colonies to other countries. Rearing facilities are checked by the national veterinary services and veterinary certificates are issued when needed. For importation, such checks and certificates usually also include honeybee parasites and diseases (notably Varroa, Tropilaelaps, Aethina and American foulbrood) even though honeybee diseases and pests are not transmitted to bumblebees. In some countries, these regulations are simply copied from those concerning honeybees, an obvious oversimplification of insect pathology and parasitology.

If managed properly, the 'set-aside' colonies produce, on average, more than 200 queens each. Males are usually produced in abundance in the same colonies and do not need to be reared separately. There is, however, a split-sex ratio in $B$. terrestris: some colonies produce males in large numbers, while others specialize in queen production (Duchateau et al., 2004).

It is important to prevent brother-sister matings, because inbreeding has immediate deleterious effects. After mating with a brother, half of the queen's diploid eggs, which normally produce females, develop into males (Duchateau et al., 1994). As a consequence, the colony produces only half the normal quantity of workers from the start and thus will remain rather small in size. Diploid males differ from haploid males in that they are smaller in size; they do, however, have larger spermatozoa. These males mate successfully, but often fail to produce viable offspring. It has also been possible to obtain triploid males and females and even a tetraploid female emerged (Duchateau et al., 1994; Duchateau and Mariën, 1995; Ayabe et al., 2004).

Mated queens are either collected directly from the mating cages or allowed to dig themselves into heaps of soil or peat. In the first case, the queens undergo pre-treatment before they are stored at $5{ }^{\circ} \mathrm{C}$. In the second case, they are dug out after some time, transferred to smaller containers, and then stored at $5{ }^{\circ} \mathrm{C}$. 
Table III. Bumblebee (sub-)species commercially reared for pollination purposes.

\begin{tabular}{|c|c|c|c|c|}
\hline Species & Origin & Used in & $\begin{array}{l}\mathrm{N} \text { colonies } \\
\text { in } 2004\end{array}$ & $\begin{array}{l}\mathrm{N} \text { workers } \\
\text { / colony }\end{array}$ \\
\hline \multicolumn{5}{|l|}{ Subgenus $\underline{\text { Bombus }}$} \\
\hline$\overline{B .}$ terrestris $\mathrm{L}$. & $\begin{array}{c}\text { Europe, North Africa, } \\
\text { West Asia }\end{array}$ & $\begin{array}{c}\text { Europe, North Africa, } \\
\text { Asia, Australasia, } \\
\text { South America }\end{array}$ & 900000 & $200-400$ \\
\hline B. t. canariensis Pérez & Canary Islands & Canary Islands & 30000 & $150-300$ \\
\hline B. lucorum $\mathrm{L}$. & Europe, Asia & East Asia & 4000 & $50-150$ \\
\hline B. ignitus Smith & East Asia & East Asia & 3500 & $100-200$ \\
\hline B. occidentalis Greene & $\begin{array}{c}\text { western North } \\
\text { America }\end{array}$ & $\begin{array}{c}\text { western North } \\
\text { America }\end{array}$ & 1000 & $200-400$ \\
\hline \multicolumn{5}{|l|}{ Subgenus Pyrobombus } \\
\hline B. impatiens Cresson & $\begin{array}{c}\text { eastern North } \\
\text { America }\end{array}$ & North America & 55000 & $300-500$ \\
\hline
\end{tabular}

\subsection{The cultivated species}

Currently, five species of bumblebees are reared commercially (Tab. III). The main species is the Eurasian B. terrestris. It has a wide distribution: all over Europe, in coastal North Africa, and in West and Central Asia (Rasmont et al., unpubl.). The wide distribution of this species was an important reason to choose it for commercial rearing. Moreover, the species was known to produce large colonies and to adapt quite well to artificial conditions. Other species have been considered and tested (e.g., B. lapidarius, van Doorn, unpubl.), but proved to be poorer choices. Comparable considerations in North America led to the choice of $B$. impatiens for the area east of the Rocky Mountains and B. occidentalis for the area west of the Rockies (see also MacFarlane et al., 1994a). In East Asia (Japan, South Korea), the B. ignitus was selected (van Doorn, unpubl.; Asada and Ono, 2000; Mah et al., 2001), whereas in China both B. ignitus and $B$. lucorum have been chosen.

Within its distribution area, B. terrestris is represented by about ten subspecies that differ in their coloration (Krüger, 1958; Rasmont et al., unpubl.). In the early years of commercialization, the Western European bumblebee producers collected (or bought) queens of several subspecies, notably B. t. terrestris from Western Europe, B. t. lusitanicus from Spain, B. t. sassaricus from Sardinia (Italy), B.t.dalmatinus from Greece and Turkey, B. t. canariensis from the Canary Islands and $B$. $t$. audax from New Zealand (where the British subspecies B. t. audax had been introduced around 1900; see Hopkins, 1914). Colonies of most of the subspecies of $B$. terrestris have been used outside their natural distribution area. Only colonies of $B . t$. $c a$ nariensis have been, and still are, exclusively used on the Canary Islands. This subspecies differs remarkably from the other subspecies with respect to its coloration. Because of this difference, together with its geographic isolation, some authors considered it a separate species (Erlandsson, 1979; Rasmont, 1984). Mitochondrial DNA analysis by Estoup et al. (1996) and crossing experiments by van den Eijnde and de Ruijter (2000), however, have confirmed its status of subspecies. The commercial rearing and use of $B$. $t$. canariensis started in 1994 and currently about 30000 colonies are used annually (Tab. III).

Many subspecies of $B$. terrestris were used in the early years of commercial rearing. From the commercial point of view, however, $B . t$. dalmatinus proved to have superior characteristics. It produces the largest colonies, and the success rate in the rearing is the highest. It has, 
therefore, become the dominant subspecies in the rearing industry (see also Tab. I). Today, $B$. terrestris colonies (mainly B. t. dalmati$n u s$ ) are used for commercial pollination not only in its Eurasian area of distribution, but also in East Asia (Japan, South Korea, China), and South America (Chile). Small numbers of $B$. t. sassaricus colonies are still being produced for Sardinia, while B. t. audax is used in New Zealand and Tasmania. We estimate that the current worldwide sales of $B$. terrestris (without B. t. canariensis) has reached some 900000 colonies per year (Tab. III).

The main species reared in North America is B. impatiens (Tab. III). Its rearing started in 1990 at Bees-Under-Glass, by Plowright. The rearing of the second species, $B$. occidentalis, has suffered from heavy infestations with the protozoan Nosema bombi since 1996. The infection most probably originated in fieldcaught queens (van Doorn, unpubl.). An infection with $N$. bombi may not be initially harmful to colony development (see Fisher and Pomeroy, 1989a; McIvor and Malone, 1995; Whittington and Winston, 2003b); however, it will eventually weaken the infected individuals (workers, queens, males) and cause their early death (de Jonghe, 1986). Moreover, heavily infected young queens are not sexually attractive and do not mate (de Jonghe, 1986). Nosema bombi is not species-specific (Schmid-Hempel and Loosli, 1998; van den Eijnde, 2000; Fries et al., 2001); however, why $B$. occidentalis is more affected than other Bombus species is unknown. The infection was noted in the rearing facilities of both North American suppliers, one of which has since completely abandoned rearing $B$. occidentalis. In order to continue supplying western North American tomato growers with bumblebee colonies, the authorities have allowed the use of $B$. impatiens with some restrictions. For example, the species is only allowed for indoor use and there is the obligatory use of the so-called 'queen-excluder' that prevents young queens from escaping. Recent research in Canadian tomato greenhouses suggests that B. impatiens is a better pollinator, with a better development of its colonies than is B. occidentalis (Whittington and Winston, 2004). At present, B. impatiens is also used in
Mexico. The total yearly sales of $B$. impatiens amount to 55000 colonies (Tab. III).

As far as East Asia is concerned, the pollination of greenhouse crops with commercially reared bumblebees started in 1992 in Japan. Discussions with Japanese bumblebee researchers revealed that the native bumblebee species that could be candidates for commercial rearing and tomato pollination were hard to rear and produced relatively small colonies (van Doorn, unpubl.). They advised, therefore, the importation of $B$. terrestris from Europe. Criticism arose about the use of this non-native species soon after it was first imported (e.g. Ono et al., 1994; Ono, 1997). This led to rearing attempts of a number of Japanese bumblebee species, both by the industry (notably $B$. ardens, $B$. diversus, $B$. hypocrita and $B$. ignitus, van Doorn, unpubl.) and by Japanese researchers (Ono et al., 1994; Hannan et al., 1997; Asada and Ono, 2000). The pollination potential for tomato crops was also examined (Asada and Ono, 1996, 1997). Similar research was initiated in South Korea (Yoon et al., 1999, 2002; Mah et al., 2001) and in China (Geng, pers. comm.). The species B. ignitus was finally chosen for commercial rearing in Japan, because of its better performance in the rearing process (van Doorn, unpubl.; compare also Asada and Ono, 2000). Although $B$. ignitus turned out to be the most suitable species, it does have some clear disadvantages compared to $B$. terrestris. For example, its rearing success rate is much lower (van Doorn, unpubl.) and full-grown B. ignitus colonies are much smaller, having about half the number of workers. These colonies, therefore, pollinate a smaller area of crop. As a result, both the production costs and the pollination costs are higher, i.e., a twofold higher price/ha when $B$. ignitus colonies are used. Japanese growers, however, are not willing to pay this price, a condition which strongly hampers the breakthrough of this species. Small numbers of $B$. ignitus colonies became available on the market in 1999 for experimentation purposes. In 2004, some 2500 B. ignitus colonies were used in a total Japanese market of 70000 colonies. Together with some 1000 colonies used in China, this comprises 3500 B. ignitus colonies (Tab. III). In 2004, besides 


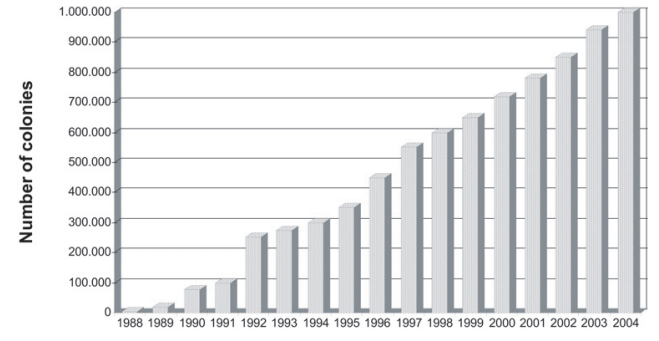

Figure 2. Assessment of worldwide sales of bumblebee colonies per year, the year numbers (19882004).

1000 B. ignitus colonies, also 4000 B. lucorum colonies and $100 \mathrm{~B}$. terrestris colonies were sold in China. In South Korea, the use of bumblebees (B. terrestris only) is estimated to involve 9000 colonies. Nowadays, although there is some local production of $B$. terrestris colonies in Japan and South Korea, most colonies used in these countries are imported from Europe. In China, however, all colonies originate from local production (Tab. I).

In 2004, the total number of colonies of all species and on all continents sold was estimated to be around one million (Fig. 2).

All of the commercially reared species (B. terrestris, B. lucorum, B. occidentalis, $B$. ignitus and $B$. impatiens) belong to two subgenera, Bombus s.s. and Pyrobombus (Richards, 1968; Williams, 1998) (Tab. III), and are so-called pollen storers. Sladen (1912) distinguished two groups of bumblebee species, pocket makers and pollen storers. The brood cells of pocket makers, which each contain a number of eggs or larvae, have pockets at their base into which the collected pollen is pressed by the foragers and from which the larvae take their food. In contrast, foragers of pollen storers deposit the collected pollen in storage pots and, from there, the house bees bring the pollen to the brood cells and feed it directly to the larvae. This behavioral difference makes pocket makers less suitable for domestication than pollen storers: pollen storers accept pollen that is placed anywhere near the brood area and carry it to the larvae, whereas pocket makers usually only accept pollen that is put inside the pockets attached to the brood cells (Griffin et al.,
1991; Reuter et al., 1994; Ptacek, 2001; van Doorn, unpubl.). Needless to say, colony feeding of the latter is much more labor-intensive. So far, good rearing results have only been obtained in pocket-making species when, after the emergence of the first workers, the colonies were allowed to collect their own food in nature (Griffin et al., 1991; Reuter et al., 1994; Ptacek, 2001). The distinction between pocket makers and pollen storers is not a rigid one (see Sakagami, 1976); for instance, both Ptacek (2001) and van Doorn (unpubl.) observed that queens and workers of the pocket makers $B$. hortorum and B. pascuorum feed individual larvae by opening the cells and inserting food into them. Ptacek (2001) also reported this behavior in $B$. ruderarius and van Doorn (unpubl.) in the Japanese pocket maker $B$. diversus. Pocket makers usually have a longer tongue than pollen storers (Sakagami, 1976) and are thus the more suitable species to pollinate flowers with deep corollas, such as red clover (Hobbs et al., 1961; Holm, 1966a). Unfortunately, plant breeders needing longtongued bumblebees cannot yet be accommodated.

\section{CROPS POLLINATED BY BUMBLEBEES AND THEIR ECONOMIC VALUE}

The main agricultural crop that bumblebees pollinate is the greenhouse tomato ( $L y$ copersicon esculentum). Worldwide, this involves about $95 \%$ of all bumblebee sales (van Doorn, unpubl.) and comprises a total of over 40000 hectares of greenhouse culture. The growing season of tomato plants in greenhouse cultures typically lasts between 7 and 11 months, depending upon the climatic conditions of the area. Up to 50 bumblebee colonies are used per hectare during the growing season. The value of these bumblebeepollinated tomato crops is estimated to be $€ 12000$ million per year.

Other crops that bumblebees pollinate (both indoor and outdoor) are listed in Table IV. The colony density needed in tomato and in other crops depends upon factors like flower density and attractiveness (Griffiths and Robberts, 
Table IV. Crops commercially pollinated by bumblebees.

\begin{tabular}{|c|c|c|}
\hline Crop & Latin name & References \\
\hline tomato & Lycopersicon esculentum & see Section 3.1 . \\
\hline pepper (sweet, hot) & Capsicum аппиит & $\begin{array}{c}\text { Shipp et al., 1994; Porporato et al., 1995; } \\
\text { Abak et al., 1997; Meisels \& Chiasson, 1997; } \\
\text { Dag \& Kammer, 2001; Kwon \& Saeed, 2003; } \\
\text { Ercan \& Onus, } 2003\end{array}$ \\
\hline eggplant & Solanum melongena & Abak et al., 1995 \\
\hline melon & Cucumis melo & Fisher \& Pomeroy, 1989b \\
\hline watermelon & Citrullus lanatus & $\begin{array}{l}\text { van Ravestijn \& Kraemer, 1991; } \\
\text { Stanghellini et al., 1997, 1998a, b, } 2002\end{array}$ \\
\hline cucumber & Cucumis sativa & Stanghellini et al., 1997, 1998b, 2002 \\
\hline courgette (zucchini) & Cucurbita pepo & \\
\hline strawberry & Fragaria $x$ ananassa & Paydas et al., 2000a, b \\
\hline raspberry & Rubus idaeus & Willmer et al., 1994 \\
\hline blackberry & Rubus fruticosus & \\
\hline currant (red, black) & Ribes sativum, $R$. nigrum & \\
\hline cranberry & Vaccinium macrocarpon & MacFarlane et al., 1994b; MacKenzie, 1994 \\
\hline blueberry & Vaccinium corymbosum, & Whidden, 1996; Stubbs \& Drummond, 2001; \\
\hline $\begin{array}{l}\text { (highbush, lowbush, } \\
\text { rabbiteye) }\end{array}$ & V. angustifolium, V. ashei & $\begin{array}{l}\text { Sampson \& Spiers, 2002; } \\
\text { Javorek et al., } 2002\end{array}$ \\
\hline apple & Malus domestica & Goodell \& Thomson, 1997; Thomson \& Goodell, 2001 \\
\hline pear & Pyrus communis & \\
\hline cherry & Prunus cerasus, $P$. avium & \\
\hline kiwifruit & Actinidia deliciosa & Pomeroy \& Fisher, 2002 \\
\hline peach & Prunus persica & \\
\hline apricot & Prunus armeniaca & \\
\hline plum & Prunus domestica & Calzoni \& Speranza, 1996 \\
\hline
\end{tabular}

1996). A cherry tomato crop, for instance, requires at least twice as many colonies per hectare than a beef tomato crop, because it contains so many flowers.

As mentioned before, bumblebees release pollen from tomato flowers by means of sonication. To do this, they grasp the anther cone with their mandibles, which leaves brown bite marks on the flowers. This behavior can damage the receptacle if the ratio bees/flowers is too high: the bees may visit individual flowers over and over again, desperately trying to release pollen, and their bites can damage the tissue which causes malformations of the fruits. This phenomenon is called over-pollination and may occur not only in tomatoes (e.g. Jackson, 1993), but also in sweet peppers (see, e.g., van Ravestijn and de Bruijn, 1991) and strawberries (see, e.g., Lieten, 1993). When this phenomenon is observed, the grower must either close the hives temporarily or remove some of them. Tomato varieties with relatively small flowers, like cherry tomatoes, are more vulnerable to overpollination than other varieties (van Doorn, unpubl.).

Honeybees can also pollinate most of the crops mentioned in Table IV, but they are often less efficient than bumblebees (see, e.g., Free and Butler, 1959; Holm, 1966a; Alford, 1975; Prys-Jones and Corbet, 1991; Goulson, 2003a; Pouvreau, 2004). Which pollinator is 
economically preferable depends on the local costs and on the climatic conditions. Bumblebees are to be preferred when the temperature and/or the light intensity are low, both in the greenhouse and in the open field. Honeybees usually do not forage at an air temperature less than $16{ }^{\circ} \mathrm{C}$, whereas bumblebee workers are still active at temperatures down to $10{ }^{\circ} \mathrm{C}$ (Heinrich, 1979). Bumblebees stop foraging when the temperature rises above $32{ }^{\circ} \mathrm{C}$ (Kwon and Saeed, 2003, for B. terrestris): they are able to fly at air temperatures up to $35^{\circ} \mathrm{C}$, but instead stay at the nest to ventilate the brood (Heinrich, 1979; Vogt, 1986). Honeybees usually treat flowers more tenderly than bumblebees and thus have a lower risk of causing over-pollination. They are known, however, to cause damage to the incipient fruits of strawberry plants (e.g., Lieten, 1993).

Sometimes it is preferable to use a number of individual bees instead of an entire colony. Minderhoud (1950), Sneep (1952) and Kraai (1958), for example, used just queens and males for the production of hybrid Brassica seeds. Similarly, small packages containing only a number of bumblebee males (with trade names like Machopol and Masculino) are used today for seed production in onions (Allium cepa), cabbages (Brassica spp.), and leeks (Allium ampeloprasum). These bees can be used only in completely enclosed environments since they would otherwise leave the place by lack of bondage to a colony.

We refrain from estimating the crop value of minor crops. In several of these crops the use of bumblebees or honeybees varies from year to year. Also, the value of bumblebees for the hybrid seed production, of mainly onion, leek, and cabbage, remains low compared to their value for tomatoes, even though the seeds are quite expensive.

The price of bumblebee colonies differs from one country to the next, depending upon the species that is reared, the volume of the market, transport costs, etc. The prices have fallen considerably during the past 15 years, because the producers have succeeded in improving the success rate of the rearing and in lowering the production costs through mechanization. Of course, competition between the producers has also added to the lower prices.
In The Netherlands, for instance, the tomato growers paid about $€ 200$ per colony during the first years (1988-1990) and less than one third of that (around $€ 50-60$ per colony) today.

Because of the strong interrelationship between bumblebee pollination and biocontrol, most bumblebee producers have started to sell not only bumblebees for pollination, but also insects, mites and microorganisms for crop protection. Unlike the major companies, smaller ones usually do not produce these crop protectors themselves, but instead buy them from other specialized companies. The total turnover of this industry (producers and distributors) can be estimated at $€ 100$ million per year; of which approximately $€ 55$ million can be attributed to bumblebees.

\section{ENVIRONMENTAL CONCERNS}

\subsection{Collecting queens from nature}

As mentioned earlier in this paper, large numbers of queens were collected from nature during the first years of commercial production, both in Europe and in North America. Many queens from distant populations were used, because they emerged from diapause several months earlier or later than those of the populations near the rearing sites. In this way, the period during which bumblebee colonies were available for pollination was extended. Southern European populations of $B$. terrestris, for example, aestivate rather than hibernate, awaking from diapause in autumn instead of spring (B.t. sassaricus, B. t. dalmatinus). Further, spring-emerging queens from New Zealand in the Southern Hemisphere (B. t. audax) were used when it was autumn in the Northern Hemisphere.

After some time, however, the massive collection of queens from nature evoked protests from the citizens of the countries involved (e.g., in Turkey; Özbek, 1993). Fortunately, the rearing companies, which had been working on the development of their own queen-rearing system since bumblebee commercialization started, had progressed so well quantitatively 
and qualitatively, that they were able to decrease the input of field-collected queens drastically. We estimate that, since approximately 1995, the worldwide use of field-collected queens has been extremely low compared to what it has been before (some hundreds per year, compared to tens of thousands).

\subsection{Introduction of non-native subspecies}

Within its distribution area, B. terrestris is represented by a number of subspecies that differ in their coloration (Krüger, 1958; Rasmont et al., unpubl.). The collection of several of these subspecies of B. terrestris and their subsequent use for pollination in regions other than where they occur naturally, have raised concern about possible genetic pollution (e.g. Ornosa, 1995). Reinforcing this concern are laboratory experiments that have shown that there is no difficulty in obtaining hybrids (de Jonghe, 1986; Duchateau, 1996; van den Eijnde and de Ruijter, 2000; van Doorn, unpubl.). However, since males and queens produced in the greenhouse do not usually appear in synchrony with those of the local population, companies and governmental authorities considered it quite improbable that genetic pollution (i.e., the introduction of alien genes and alleles into the local population) would take place. It seemed equally improbable that greenhouse-mated queens, after escaping from that environment, would be successful in producing sexuals. Such colonies would develop outside the local bumblebee season and, therefore, they would suffer from adverse climatic and foraging conditions. Even if an occasional sexual would be produced in such colonies, it would find no partner to mate with. As a result, no measures have been taken in most countries in Europe; exceptions are the Canary Islands (belonging to Spain) and Norway, as well as the West Asian countries Turkey and Israel. The authorities of the Canary Islands decided that only the local subspecies, B. terrestris canariensis, could be used for pollination purposes. They do, however, allow the rearing of this subspecies in production facilities on the mainland and the subsequent importation of the colonies. The Norwegian authorities do not allow the importation of colonies from outside the country and required the local production of the endemic strain of B. terrestris, B. t. terrestris. The Dutch and Belgian bumblebee producers decided not to build a rearing facility in Norway because of the very small size of the Norwegian market. Three small local producers now service that market (see Tab. I). In the Middle East (West Asia), neither the Israeli nor the Turkish authorities allow the importation of bumblebee colonies from outside the country. As a result, with the aid of Dutch and Belgian bumblebee producers, local rearing facilities have been established using the native species $B$. terrestris, subspecies $B$. $t$. dalmatinus (see Tab. I). The difference in size between the Israeli and Turkish markets on the one hand, and the Norwegian market on the other, explains the selective involvement of the Dutch and Belgian producers.

In Section 3, we showed that B. t. dalmatinus, at the expense of the other subspecies, has become the main subspecies used by European and West Asian bumblebee producers. Clearly, this subspecies is employed outside its natural distribution area. In the past, B. $t$. sassaricus, endemic on the Mediterranean island Sardinia, has been one of the subspecies used in Western Europe. This subspecies has two obvious characteristics that distinguish it from the other subspecies: B. t. sassaricus has red instead of black hind legs and brown instead of white hairs on its abdominal tip. The inheritance of the color on the legs is simple: a single locus with two alleles controls this color difference, the one for black being dominant over the one for red in the diploids (Duchateau, unpubl.). This characteristic can be used to detect the subspecies' settlement in rural areas (finding workers with red hind legs) and hybridization with field populations (50\% of the sons from the hybrid queens and F1 workers have red hind legs). Therefore, we made an inquiry among Dutch and Belgian hymenopterists concerning the presence of signs of $B$. $t$. sassaricus among the natural population of $B$. t. terrestris. However, this did not provide much evidence of hybridization despite the large numbers of colonies 
used in the greenhouses. Dr. Rasmont could not report the appearance of hybrids in Belgium. However, he once observed B. $t$. sassaricus workers collecting pollen in Southern France, which he considered proof of successful colonization. In later years, however, he was unable to find this subspecies at that locality. In The Netherlands, Peeters considers the various deviating color patterns in $B$. terrestris part of the natural variation. Roos has males and a queen of B. t. sassaricus, caught in spring, in his collection. Probably most if not all of them are individuals escaped from greenhouses, considering the localities and the dates of collection. In addition, he collected individuals of $B$. $t$. terrestris with abnormal color patterns, a deviation that not necessarily arose by hybridization with $B$. $t$. sassaricus (see Peeters' remark above). Settlement, successful competition and hybridization with local bumblebees, therefore, appear to be at most rare events. In conclusion, notwithstanding the previous extensive use of B.t. sassaricus in Dutch and Belgian greenhouses, neither the occurrence of its colonies in the field, nor its hybridization with $B$. t. terrestris has been irrefutably documented so far.

B. t. dalmatinus does not have distinct morphological characteristics that allow being easily detected in the field. Molecular studies, therefore, appear necessary to find evidence of hybridization. Such hybridization is expected, however, and sooner or later such an effect of the long-distance transportation of B. $t$. dalmatinus will be noticeable in areas where other subspecies are native.

\subsection{Introduction of non-native species}

As already mentioned, queens of four bumblebee species (B. hortorum, B. ruderatus, $B$. subterraneus and $B$. terrestris), originating from the U.K., were introduced into New Zealand in 1885 and 1906 and became established there. The purpose of these introductions was to improve the seed set of red clover, an important fodder for cattle and horses at that time (Hopkins, 1914). Today, the introduced $B$. terrestris, subspecies B. t. audax, is commercially reared in New Zealand for the pollination of tomatoes and other crops (see Tab. I).

In 1992 B. t. audax, most probably originating from New Zealand, arrived in Tasmania. This occurred either accidentally or intentionally (Semmens et al., 1993; Buttermore, 1997). Since then it has expanded its distribution in Tasmania by about $10 \mathrm{~km}$ per year and the number of colonies has increased rapidly. Interactions with the local bee fauna have also been reported (Hingston and McQuillan, 1998a, b, 1999; Stout and Goulson, 2000; Hingston et al., 2002; Stout et al., 2002). In 2000, Stout and Goulson specifically discussed the high probability that B. t. audax would colonize mainland Australia at some time and, indeed, in 2003, both workers and queens of B.t. audax were found at or near ports on the mainland. It was supposed they had arrived as stowaways on ships from New Zealand (Dollin, 2003). That is possible; however, since European bumblebees had been introduced in New Zealand more than a century earlier and during that period of time no stowaway mated queen had succeeded in arriving and reproducing on the Australian continent, it seems more likely that the queens either came from Tasmania by island-hopping (Stout and Goulson, 2000) or were imported illegally. Whatever the case, Australian tomato growers would very much like to start using bumblebees to pollinate their tomato crops, because they have seen the advantages obtained on other continents (Hergstrom et al., 2002; Griffiths, 2004). Native Australian bees (Amegilla, Xylocopa) are currently being studied with respect to their potential as tomato pollinators and their suitability for indoor rearing (Hogendoorn et al., 2000, 2006; Hogendoorn, 2004).

In North America, the eastern species B. impatiens is also currently being used in the western part of the continent (see Sect. 3.3). Discussions about its use in the western part of the continent have stimulated researchers in British Columbia to study the possibilities of using honeybees instead of bumblebees (Sabara and Winston, 2003; Higo et al., 2004; Sabara et al., 2004). Sabara et al. (2004) showed that honeybees are only a suitable alternative during the winter season, supporting 
earlier studies in The Netherlands (van Duyn, 1988; de Ruijter and de Bruijn, 1989).

Since 1994, B. impatiens colonies have been imported to Mexico from Canada and the USA. Because of ecological concerns, some Mexican research institutes have recently started to rear the native species B. ephippiatus (Torres, pers. comm.). Even more recently, tomatoes have been pollinated successfully using the stingless bee species, Nannotrigona perilampoides (Cauich et al., 2004). The authors note, however, that more research is needed on the biology of this latter species, before it can be used commercially. The same holds for the many other stingless bee species (Heard, 1999).

The first intentional introduction of a European bumblebee species into South America occurred in 1982 when B. ruderatus queens were brought from New Zealand to Chile for the pollination of red clover (Arretz and MacFarlane, 1986). They have since established themselves in nature. In 1998, B. terrestris colonies started being imported from Europe and West Asia (Ruz and Herrera, 2001). In fact, many of the B. terrestris colonies used in Chile today are produced in Europe and West Asia, although there is local production (see Tab. I). Ruz and Herrera (2001) reported that $B$. terrestris was "detected for the first time in wilderness", which may lead to the conclusion that this species has also become established in Chile.

As expected, discussions on the ecological impact of these importations have also started in Chile (Ruz and Herrera, 2001). Unfortunately, alternatives are not readily available. The native species $B$. dahlbomii has been shown to pollinate tomatoes in Chilean greenhouses (Estay et al., 2001), but it belongs to the group of pocket makers (see Sect. 3) and is thus difficult to propagate. Moreover, the colonies remain small. A second candidate, $B$. ruderatus, probably produces bigger colonies, but is also a pocket maker.

In the past years few Argentine tomato growers also applied for the importation of $B$. terrestris colonies. The native bumblebee fauna of Argentina only consists of pocketmaking species (compare Abrahamovich et al., 2001, and Williams, 1998), including the Eu- ropean $B$. ruderatus, which probably travelled from Chile to Argentina. A permit for importation was not, however, issued, so the Argentine tomato growers must still use traditional methods of artificial pollination.

Similarly, Brazil does not allow the importation of non-native bumblebee colonies. The stingless bee Melipona quadrifasciata was recently tested as a pollinator of greenhouse tomatoes, with positive results (Del Sarto et al., 2005). Unfortunately, this bee cannot be used on a larger scale yet, because, as the authors state, the sole current method for acquiring new colonies is to remove them from the forest. Techniques, therefore, must first be developed for colony multiplication in order to prevent a serious decline in wild populations.

Colonies of B. terrestris have been imported into East Asia (Japan, South Korea, China) since 1992. The majority of these colonies was, and still is, produced in Western Europe. To date, however, some local production of B. terrestris also occurs (see Tab. I). Worries about this importation practice have been expressed by several authors (Ono et al., 1994; Ono, 1997; Goka et al., 2001; Yoon et al., 2002; Matsumura et al., 2004). Ono (1997), for example, reported that, in laboratory experiments, when $B$. terrestris queens were introduced into nest boxes containing incipient colonies of the consubgeneric species B. ignitus and B. hypocrita (subgenus Bombus s.s.; Richards, 1968; Williams, 1998), the $B$. terrestris queen succeeded in usurping the $B$. ignitus nest (and killing its queen). This was not so with $B$. hypocrita. Such intra- and interspecific nest usurpation is characteristic of many bumblebee species (see Sakagami, 1976). Ono (1997) also found that males of $B$. terrestris mated with queens of both consubgeneric species. However, these mated queens usually failed to produce any offspring. Ono (1997) further reported the first discovery of a feral colony of $B$. terrestris on the northern island Hokkaido in 1996. Goka et al. (2001) found tracheal mites (Locustacarus buchneri) in commercially reared colonies of $B$. terrestris and B. ignitus, both produced in Europe, and established through mtDNAanalysis that these mites differed genetically from the ones occurring naturally in Japan. 
They also warned about the possible related dangers. Matsumura et al. (2004) reported on the establishment of $B$. terrestris in Japan; since 1996, colonies of $B$. terrestris have been witnessed not only on Hokkaido, but also in central Japan. Matsumura et al. (2004) also reported about resource overlap between feral $B$. terrestris individuals and native bumblebees: $40-70 \%$ of the plant species visited by $B$. terrestris individuals were also visited by native bumblebees. Finally, they speculated about a possible competition for nest sites: $B$. terrestris queens used nest sites that were similar to those chosen by the native species $B$. hypocrita sapporoensis and $B$. diversus tersatus (both subspecies endemic to Hokkaido).

These reports of ecological impact led the Japanese government to include B. terrestris in the Invasive Alien Species Act (Wada and Mitsuhata, pers. comm.). The consequences of this are not yet clear, but most probably B. terrestris will be banned in the long run. In the meantime, Japanese growers will probably be forced to use screens in their greenhouses in order to prevent $B$. terrestris individuals from escaping. B. terrestris will not be banned immediately, because the production of the native alternative, B. ignitus (see Sect. 3), is still limited. In fact, for the Japanese market, there are only two suppliers of this species (Koppert and Biobest) at the moment. Other producers are being given the opportunity to start rearing the species.

In Africa, bumblebees occur naturally north, but not south of the Sahara. Some years ago, South African researchers applied for the importation of $B$. terrestris colonies from Europe and/or West Asia. Although some colonies were imported for experimental purposes, commercial importation was and still is not allowed.

\subsection{Natural expansion}

B. terrestris (subspecies B. t. dalmatinus) is native to the northern part of Israel (Upper Galilee). Since 1930 it has been observed to expand its territory in a southernly direction, reaching gardens at Mt. Carmel in 1978 (Dafni and Shmida, 1996). From 1980 to 1994 Dafni and Shmida (1996) counted the number of bees per species on just one tree of Arbutus andrachne on Mt. Carmel. They found a decrease in the number of all bee species, except $B$. terrestris. Instead, the number of $B$. terrestris individuals increased during that period. The authors argued that the increase in the human population in this area has led to an abundance of irrigated gardens in the settlements. These gardens provide food sources for these bumblebees during the dry summer periods, without which the colonies would be unable to complete their cycle. On the other hand, the increase in the human population has caused the destruction of the habitats needed by the other bee species (notably through fires), and thus their decline. In discussions about the possible impact of the introduction of non-native bumblebees, the expansion of B. terrestris on Mt. Carmel has often been used as an example to illustrate the negative effects of such introductions. As outlined above, however, this example is highly questionable on that point.

The agricultural use of bumblebees in Israel started in 1991 (B. t. dalmatinus, reared in Israel; see Tab. I). The colonies are used in greenhouses all over the country and nowadays there is an increasing number of reports concerning feral $B$. terrestris queens and workers at these locations. Dafni (1998) stated that this recent expansion of $B$. terrestris might be a threat to the local bee fauna as well as to the flora, but did not discuss the possible impact of primary anthropogenic alterations of the environment.

\subsection{Balancing ecological and economic arguments}

Like most studies on the impact of introduced honeybees and solitary bees on native bees (reviewed by Butz Huryn, 1997; Goulson, 2003b, 2004; Paini, 2004), studies on the impact of introduced bumblebees have focused on floral resource overlap, visitation rates and/or resource harvesting (e.g., Hingston and McQuillan, 1998a, b, 1999; Ruz and Herrera, 2001; Hingston et al., 2002; Stout et al., 2002). Contrary to what is often assumed, the available data concerning the impact of introduced 
honeybees show that the effects on native fauna and flora are relatively subtle, especially when compared to other introductions and habitat losses (Butz Huryn, 1997; Paini, 2004). One should remember, however, that it is very difficult to produce hard evidence for ecological damage to an ecosystem due to a new species: if two species are using similar nest sites or visiting the same flowers, one needs to demonstrate that this condition has an impact on the reproductive success of either species. The complexity of ecosystems, however, usually precludes such straightforward conclusions. Researchers, therefore, extrapolate from their observations. Given the number of cases where introductions of foreign animals or plants into new areas have been detrimental, precautions must always be taken when there is no hard evidence (which can only be found once the damage is done).

Because economic perspectives usually dominate decision-making, the Eurasian bumblebee $B$. terrestris is now widely used outside its natural distribution area, notably in Japan, South Korea, and Chile, and the eastern North American B. impatiens in western North America and Mexico. This often involves long-distance transportation. Technically, it is possible to rear colonies locally, in quantities, and at times whenever they are needed. This type of rearing, however, has a somewhat seasonal character. Starting the production anew each year takes much more effort than continuation, which makes locally produced colonies much more expensive than those that come from a year-round producer. Unfortunately, this is the economic mechanism that has prevented the emergence of a network of local production sites and has led to the situation that there are only a few large production companies that deliver to many national wholesalers. The potential risks of this concentrated production have been implicitly accepted.

From the viewpoint of safety and nature protection, local production, preferably of a local pollinating species, should be encouraged. In any country, the local tomato varieties can most probably be pollinated by those native bees that already prefer the native Solanaceae. If there is concern about the dangers adher- ing to importation, both the government and the farmers should invest in research. Indeed, several studies have been performed to date (Hogendoorn et al., 2000, 2006; Estay et al., 2001; Sabara and Winston, 2003; Cauich et al., 2004; Higo et al., 2004; Hogendoorn, 2004; Sabara et al., 2004; Del Sarto et al., 2005) and have shown that the major obstacle is the mass-rearing of alternative pollinators. As long as this aspect has not been overcome, there is a high risk that nature will be robbed again of native bees. As we have shown, even though there is no shortage of biologists capable of doing that job, the development of an alternative pollination procedure takes time. In the meantime, however, farmers will continue pressuring their government for quick access to the foreign technology, and illegal action cannot be excluded.

In spite of the possible adverse effects, we do not categorically reject the use of bumblebee (sub)species outside their natural geographic area of distribution. In our view, the following elements have to be taken into consideration:

1. Bumblebee-pollinated tomatoes have a better quality, usually contain less residues of insecticides and can be produced at lower costs compared to those that were produced by means of mechanical vibration or hormone treatment. Farmers using these older methods, when in competition with those other farmers that use bumblebees, are in an economically inferior position. If their government does not allow them to use bumblebees, imports of bumblebee-pollinated tomatoes will ruin their financial prospects.

2. Companies that sell bumblebee colonies compete among each other. This has the advantage that it leads to lower prices for their products, but the disadvantage of forcing them to concentrate their production as much as governments allow them. Small markets are not served if it would imply high expenses to do so. Therefore, small markets are inhibited to formulate their own, specific conditions for providing them with a specified kind of bumblebee colony.

3. Worldwide use of a limited number of bumblebee species, often outside their natural geographic area of distribution, indeed 
implies that a number of environmental risks are implicitly accepted: hybridization with local subspecies or species, competition with other (bumble)bees for food and nest sites, introduction of harmful organisms etc. But, what would be acceptable and what would be a disaster? This can not be predicted on sound scientific grounds. Some prefer to be rather rigid in this matter, but this goes along with the obligation to find a real alternative for the farming industry. It will take time before such an alternative has been developed to the point that it can be included in the farming technology, and introduced on a large scale. Moreover, the economic elements of items 1 and 2 are difficult to weigh against the desire to keep the ecosystems intact.

Logically, representatives of different professional groups do weigh these elements differently. Small scale, local use of biological resources such as pollinators seems to be the ideal situation for many of those that are working in the field. However, living in a globalized world, it appears to be quite unrealistic to expect, or demand, that such ecologically fitting systems will ever be fully developed and maintained. This is regrettable, but, in our opinion, one should be pragmatic. It is for that reason that there should be a government that makes the decision whether introduction of an alien bumblebee is granted or not. Biologists of various kinds should be among the advisers of such a government, but there should also be economists, agriculturists etc. In this paper, we relate what has happened. At some places we have expressed our own view, but we kept this to a minimum. We prefer to keep our paper as scientifically sound as possible and, therefore, we refrain from speculation. This does not mean that we do not have opinions and concerns. But we believe that those should be expressed in papers intended for politicians, whose profession it is to decide about steps in the dark.

\section{GENERAL CONCLUSIONS}

This paper reports that it took almost a century of research and discussions about its potentials before the commercial rearing of bum- blebees actually began. Since its start in 1987, however, commercial rearing has expanded rapidly, with up to an annual production of 1 million colonies in 2004. At present, five species of bumblebees are being reared, the major two being Bombus terrestris from Eurasia and Bombus impatiens from North America. These species are predominantly used in caged tomato crops. The vegetable, fruit and seed growers who use bumblebees for pollination benefit from lower production costs, increased yields, and an improved quality of their products. In addition, the application of bumblebees for pollination has stimulated growers to change to biocontrol methods for crop protection. The consumers and the environment also benefit from this development: consumers get a better, tastier, and healthier product, while fewer residues of harmful pesticides are released into the environment. Of course, the initial advantages of lower production costs and higher crop value soon evaporated because the large majority of the growers decided to use the new technology. The other advantages (for the consumers and the environment), however, persist.

This paper also states that the worldwide application of bumblebees (where it concerns their use outside their natural distribution area) carries environmental risks. The first risk was a depletion of natural resources. In the early years of commercial bumblebee rearing, large numbers of queens were collected from nature. Today this is no longer the case. The second, genetic pollution through hybridization with local subspecies, may occur when different subspecies become mixed, although there is no evidence yet to support this. Other worries include the establishment of introduced bumblebee species (or the expansion of a native species) in landscapes occupied by other bee species, which could endanger the indigenous fauna. This establishment has already occurred in a number of countries, both in the past (in New Zealand) and more recently (in Chile, Tasmania, and Japan). Although there are interactions with the native bee fauna, severe damage has not yet been reported.

In our opinion, some lessons can and must be learned from this bumblebee story. Although many wild bee species are potentially 
important economically for agriculture, prudence should prevail in attempts to disclose their potency. As soon as a glimpse of profit emerges, commercial arguments will usually overrule all other considerations. Further, the development of the bumblebee industry has shown that, when rearing technology has not yet been sufficiently developed, nature will be robbed to satisfy the market. Finally, economic aspects have led to the concentrated production of just a few species, while the ecological consequences of the introduction of these colonies into areas where they do not belong naturally has had less emphasis in decisionmaking than the advantages growers expect to have. Fortunately, great disasters have not occurred so far, even though the risks were not sufficiently avoided. These conclusions are especially of interest now that the International Pollinator Initiative has received support. Convergence of the expectations of the parties involved is necessary to reduce the chance that negative effects of such an enjoyable enterprise may arise.

\section{ACKNOWLEDGEMENTS}

Many of the data on the extent of commercial production and use of bumblebee colonies were made available by Koppert Biological Systems. This help, and this openness, is very much appreciated. Linguistic advice was given by Laura Cobb.

Résumé - Un siècle de progrès dans la domestication des bourdons et aspects économiques et écologiques de leur commercialisation pour la pollinisation. D'un point de vue historique, le développement de la technique d'élevage des bourdons (Bombus spp.) se caractérise par trois phases. Durant la $1^{\text {re }}$ phase, les reines ont été attirées dans des domiciles artificiels et diverses techniques ont été utilisées pour stimuler les reines à fonder une colonie. Les connaissances acquises durant cette phase ont rendu possibles les études de terrain concernant la biologie des bourdons. Elles ont aussi été utilisées pour améliorer la pollinisation des cultures dont la floraison était synchrone du développement naturel des colonies. La compréhension grandissante des mécanismes qui régulent l'activation des reines et leur production d'oeufs et des mécanismes qui gouvernent la colonie dans son ensemble a permis aux chercheurs d'élever des bourdons toute l'année. La $3^{\mathrm{e}}$ phase a vu la transition vers l'élevage commercial, technique qui nécessite une connaissance plus détaillée des moyens pour maximiser la réussite de l'élevage. En moins de 20 ans, l'élevage commercial a atteint une production annuelle d'un million de colonies. Bien que de nombreuses espèces, parmi les 250 existantes, aient été élevées, seules cinq espèces sont utilisées dans les programmes de pollinisation (Tab. III). Parmi ces cinq espèces, l'espèce eurasienne Bombus terrestris est de loin la plus importante sur le plan commercial, suivie par l'espèce nord-américaine Bombus impatiens. Le tableau I fournit des détails sur les pays qui utilisent ces espèces et sur les sociétés qui les produisent et les vendent. L'acceptation rapide des bourdons et leur vaste introduction en tant que pollinisateurs peut s'expliquer par les avantages économiques par rapport aux techniques plus anciennes, souvent artificielles. La figure 1 montre la transition rapide qui s'est opérée dans le cas des tomates sous serre aux Pays-Bas. Et la figure 2 l'accroissement des ventes mondiales. Le tableau II présente l'évolution dans le temps de l'expansion mondiale.

Aujourd'hui les bourdons sont utilisés pour la production agricole sur tous les continents. Bien qu'ils pollinisent des cultures de plein champ et des cultures sous cage (Tab. IV), leur utilisation prédomine dans la production de tomates sous serre. Celle-ci couvre 40000 ha et représente une valeur de 12000 millions d'euros. La pollinisation par les bourdons entraîne une baisse des coûts de production, un accroissement des rendements et une meilleure qualité des fruits, ainsi qu'une plus grande utilisation de la lutte biologique contre les ravageurs des cultures. A cause de l'acceptation générale de la nouvelle technologie, les gains financiers pour les agriculteurs ont rapidement disparus tandis que le consommateur a continué de bénéficier d'une meilleure qualité.

La plupart des colonies ne sont produites que par un petit nombre de sociétés et sont transportées sur de longues distances. En fait elles sont expédiées dans des régions éloignées de leur habitat d'origine. Il est donc justifié d'avoir des craintes sur les conséquences écologiques. Par exemple, B. terrestris a récemment été implanté au Japon, au Chili et en Tasmanie. Là, il entre en compétition avec les espèces indigènes et peut transmettre des parasites et des pathogènes de bourdons à de nouveaux hôtes. Il faut donc préférer la production locale de pollinisateurs autochtones.

Toutefois, d'un point de vue commercial, une production centralisée est préférable car c'est le moyen le plus économique de produire des colonies. Ces conflits d'intérêts entre conservation et commerce ne peuvent être résolus que par des recherches appropriées qui conduiront à des alternatifs utilisant des abeilles indigènes et qui incluront la production contrôlée de ces insectes sur une base commerciale. Si le développement d'une telle production commerciale échouait, cela pourrait aboutir à 
des dégâts écologiques, parce que les agriculteurs voulant utiliser cette nouvelle technique de pollinisation pourraient récolter les insectes dans la nature. Une attitude passive des gouvernements et des organisations agricoles pourrait donc avoir des effets nuisibles. En même temps les conservationnistes doivent se rappeler que l'un des arguments qui soutient largement la conservation de la nature est que la nature recèle des propriétés encore inconnues, susceptibles d'être bénéfiques pour notre santé, notre bien-être et notre prospérité.

\section{Bombus / pollinisation / élevage commercial / valeur économique / impact écologique}

\section{Zusammenfassung - Ein Jahrhundert des Fort- schritts bei der Domestikation von Hummeln und die ökonomischen und ökologischen Aspek- te ihrer Kommerzialisierung für die Bestäu-} bung. Die historische Entwicklung der Haltung von Hummeln lässt sich in drei Phasen einteilen. In der ersten Phase wurden Königinnen in künstliche Nistkästen gelockt und vielfältige Techniken wurden zur Stimulation der Volksgründung angewendet. Die in dieser Phase erworbenen Kenntnisse ermöglichten Feldstudien über die Biologie der Hummeln und wurden ebenfalls genutzt, um die Bestäubung von denjenigen Nutzpflanzen zu verbessern, welche synchron mit der natürlichen Entwicklung der Völker blühen. In der zweiten Phase wurden im Freiland überwinterte Hummelköniginnen im Labor erforscht. Sowohl das wachsende Verständnis über die regulierenden Mechanismen zur Aktivierung und Eiproduktion individueller Königinnen als auch über Mechanismen, die das Sozialverhalten des ganzen Volkes regulieren, ermöglichte schließlich eine ganzjährige Zucht von Hummeln. In der dritten Phase erfolgte ein Übergang in eine kommerzielle Hummelzucht, eine Technologie, für die eine noch genauere Kenntnis über die Maximierung des Zuchterfolges notwendig wurde. In weniger als 20 Jahren ist die kommerzielle Zucht auf über eine Million Völker angestiegen. Obwohl viele der 250 noch vorhandenen Arten gezüchtet wurden, werden nur fünf in Bestäubungsprogrammen eingesetzt (Tab. III). Von diesen fünf Arten ist die eurasische Bombus terrestris kommerziell die bei weitem erfolgreichste, gefolgt von der nordamerikanischen Bombus impatiens. Tabelle I zeigt die Länder im einzelnen auf, die diese Arten nutzen und die Firmen, die sie züchten und verkaufen. Die schnelle Akzeptanz und die weitläufige Einführung der Hummeln als Bestäuber erklärt sich durch die ökonomischen Vorteile gegenüber der alten künstlichen Bestäubungstechnik. Abbildung 1 zeigt den schnellen Übergang, der bei den Tomaten im Gewächshaus in den Niederlanden erfolgte und Abbildung 2 die Zunahme des weltweiten Handels. Tabelle II zeigt zeitliche Aspekte der weltweiten Expansion.
Heute werden Hummeln auf allen Kontinenten in der Landwirtschaft eingesetzt. Obwohl viele Nutzpflanzen sowohl im Feld als auch unter Folien oder Glas von den Hummeln bestäubt werden (Tab. IV), werden sie vor allem bei der Produktion von Tomaten in Gewächshäusern eingesetzt. Letztere umfasst 40000 ha und eine Ernte im Wert von 12 Milliarden Euro. Die Bestäubung durch Hummeln führt zu geringeren Produktionskosten, höheren Ernten, besserer Qualität und mehr biologisch orientierter Schädlingsbekämpfung. Durch die allgemeine Akzeptanz der neuen Technik waren die finanziellen Gewinne der Landwirte von kurzer Dauer, dagegen blieb die gestiegene Qualität den Verbrauchern erhalten.

Die meisten Völker werden von nur wenigen Firmen erzeugt und über große Entfernungen transportiert. Sie werden auch in Gebiete geschickt, die weit von ihrem natürlichen Habitat entfernt sind. Daher sind Befürchtungen über ökologische Folgen berechtigt. Zum Beispiel siedelte sich $B$. terrestris kürzlich in ländlichen Gebieten von Japan, Chile und Tasmanien an. Dort konkurriert sie mit einheimischen Arten und könnte Hummelparasiten und Pathogene auf diese übertragen. Die lokale Zucht von einheimischen Arten sollte daher bevorzugt werden. Kommerziell jedoch ist die zentrale Zucht ertragreicher. Dieser Konflikt von Naturschutz und kommerziellen Interessen kann nur durch zeitaufwendige Untersuchungen gelöst werden, die zu alternativen Bestäubersystemen mit einer kontrollierten Zucht dieser Insekten auf kommerzieller Basis führen. Ein Misserfolg in der Entwicklung einer kommerziellen Zucht könnte zu einem ökologischen Schaden führen, weil die Landwirte, die diese neue Bestäubungstechnik nutzen wollen, die Insekten in der Natur sammeln könnten. Eine passive Haltung der Regierung und der Landwirtorganisationen könnten daher schlimme Auswirkungen haben. Gleichzeitig sollten Naturschützer daran denken, dass eines der Argumente, das den Naturschutz stark unterstützt, beinhaltet, dass die Natur immer noch unentdeckte Eigenschaften hat, die zu unserer Gesundheit, unserem Wohlbefinden und Wohlstand beitragen.

Bombus / Bestäubung / kommerzielle Zucht / ökonomischer Wert / ökologischer Einfluss

\section{REFERENCES}

Abak K., Sari N., Paksoy M. (1995) Efficiency of bumble bees on the yield and quality of eggplant and tomato grown in unheated glasshouses, Acta Hortic. 412, 268-274.

Abak K., Dasgan H.Y., Ikiz O., Uygun N., Sayalan M., Kaftanoglu O., Yeninar H. (1997) Pollen production and quality of pepper grown in unheated greenhouses during winter and the effects of bumblebees (Bombus terrestris) pollination on fruit yield and quality, Acta Hortic. 437, 303-307. 
Abrahamovich A.H., Tellería M.C., Díaz N.B. (2001) Bombus species and their associated flora in Argentina, Bee World 82, 76-87.

Alford D.V. (1975) Bumblebees, Davis-Poynter, London.

Arretz P.V., MacFarlane R.P. (1986) The introduction of Bombus ruderatus to Chile for red clover pollination, Bee World 67, 15-22.

Asada S., Ono M. (1996) Crop pollination by Japanese bumblebees, Bombus spp. (Hymenoptera: Apidae): tomato foraging behaviour and pollination efficiency, Appl. Entomol. Zool. 31, 581-586.

Asada S., Ono M. (1997) Tomato pollination with Japanese native bumblebees (Bombus spp.), Acta Hortic. 437, 289-292.

Asada S., Ono M. (2000) Difference in colony development of two Japanese bumblebees, Bombus hypocrita and Bombus ignitus (Hymenoptera: Apidae), Appl. Entomol. Zool. 35, 597-603.

Aupinel P., Génissel A., Gomond S., Tasei J.-N., Poncet J. (2001) Collection of spring pollens by Bombus terrestris queens, assessment of attractiveness and nutritive value of pollen diets, Acta Hortic. 561, 101-105.

Ayabe T., Hoshiba H., Ono M. (2004) Cytological evidence for triploid males and females in the bumblebee, Bombus terrestris, Chromosome Res. 12, 215-223.

Baer B., Schmid-Hempel P. (2000) Applied aspects of the artificial insemination for bumblebees, in: Sommeijer M.J., Ruijter A. de (Eds.), Insect pollination in greenhouses, Utrecht University \& Ambrosiushoeve, Utrecht, Hilvarenbeek, pp. 3133.

Baer B., Morgan E.D., Schmid-Hempel P. (2001) A nonspecific fatty acid within the bumblebee mating plug prevents females from remating, Proc. Natl Acad. Sci. USA 98, 3926-3928.

Banda H.J., Paxton R.J. (1991) Pollination of greenhouse tomatoes by bees, Acta Hortic. 288, 194198.

Barrow D.A., Pickard R.S. (1985) Larval temperature in brood clumps of Bombus pascuorum (Scop.), J. Apic. Res. 24, 69-75.

Beekman M., Stratum P. van, Lingeman R. (1998) Diapause survival and post-diapause performance in bumblebee queens (Bombus terrestris), Entomol. Exp. Appl. 89, 207-214.

Beekman M., Stratum P. van, Veerman A. (1999) Selection for non-diapause in the bumblebee Bombus terrestris, with notes on the effect of inbreeding, Entomol. Exp. Appl. 93, 69-75.

Bilinski M. (1976) Chow trzmieli w isolatorach, Pszcz. Zesz. Nauk. 20, 41-67.

Bilinski M. (1977) Method for rearing bumblebees in cages, Bee Research Copies 21, 237-241.
Bilinski M. (2000) Wintering in bumblebee queens - Bombus terrestris (L.), in: Sommeijer M.J., Ruijter A. de (Eds.), Insect pollination in greenhouses, Utrecht University \& Ambrosiushoeve, Utrecht, Hilvarenbeek, pp. 49-51.

Bogaard R. van den (1991) Hommels hebben hun werk prima gedaan, Groenten en Fruit / Glasgroenten 43 (25 oktober), pp. 14-15.

Bohart G.E. (1972) Management of wild bees for the pollination of crops, Annu. Rev. Entomol. 17, 287-312.

Bornus L. (1975) Hummelzuchtversuche haben eine reiche Tradition, Bull. Tech. Apic. 2, 279-290.

Bosch J., Kemp W.P. (2001) How to manage the blue orchard bee as an orchard pollinator, Sustainable Agriculture Network Handbook Series, Book 5, National Agricultural Library, Beltsville, MD.

Brown M.J.F., Baer B., Schmid-Hempel R., SchmidHempel P. (2002) Dynamics of multiple-mating in the bumble bee Bombus hypnorum, Insectes Soc. $49,315-319$.

Buchmann S.L. (1983) Buzz pollination in angiosperms, in: Jones C.E., Little R.J. (Eds.), Handbook of experimental pollination biology, Van Nostrand-Rheinhold, New York, pp. 73-113.

Buttermore R.E. (1997) Observations of successful Bombus terrestris (L.) (Hymenoptera: Apidae) colonies in Southern Tasmania, Aust. J. Entomol. 36, 251-254.

Butz Huryn V.M. (1997) Ecological impacts of introduced honey bees, Q. Rev. Biol. 72, 275-297.

Calzoni G.L., Speranza A. (1996) Pear and plum pollination: honey bees, bumble bees or both? Acta Hortic. 423, 83-90.

Cameron S.A. (1985) Brood care by male bumble bees, Proc. Natl Acad. Sci. USA 82, 6371-6373.

Cane J.H. (1997) Ground-nesting bees: the neglected pollinator resource for agriculture, Acta Hortic. 437, 309-324.

Cauich O., Quezada-Euán J.J.G., Macias-Macias J.O., Reyes-Oregel V., Medina-Peralta S., Parra-Tabla V. (2004) Behavior and pollination efficiency of Nannotrigona perilampoides (Hymenoptera: Meliponini) on greenhouse tomatoes (Lycopersicon esculentum) in subtropical México, J. Econ. Entomol. 97, 475-481.

Cnaani J., Schmid-Hempel R., Schmidt J.O. (2002) Colony development, larval development and worker reproduction in Bombus impatiens Cresson, Insectes Soc. 49, 164-170.

Dafni A. (1998) The threat of Bombus terrestris spread, Bee World 79, 113-114.

Dafni A., Shmida A. (1996) The possible ecological implications of the invasion of Bombus terrestris (L.) (Apidae) at Mt Carmel, Israel, in: Matheson A., Buchmann S.L., O'Toole C., Westrich P., Williams I.H. (Eds.), The conservation of bees, Academic Press, London, pp. 183-200. 
Dag A., Kammer Y. (2001) Comparison between the effectiveness of honey bee (Apis mellifera) and bumble bee (Bombus terrestris) as pollinators of greenhouse sweet pepper (Capsicum annиum), Am. Bee J. 141, 447-448.

Dasgan H.Y., Özdogan A.O., Kaftanoglu O., Abak K. (2004) Effectiveness of bumblebee pollination in anti-frost heated tomato greenhouses in the Mediterranean Basin, Turk. J. Agric. For. 28, 73-82.

Day S., Beyer R., Mercer A., Ogden S. (1990) The nutrient composition of honeybee-collected pollen in Otago, New Zealand, J. Apic. Res. 29, 138-146.

Del Sarto M.C.L., Peruquetti R.C., Campos L.A.O. (2005) Evaluation of the neotropical stingless bee Melipona quadrifasciata (Hymenoptera: Apidae) as pollinator of greenhouse tomatoes, J. Econ. Entomol. 98, 260-266.

Dogterom M.H., Matteoni J.A., Plowright R.C. (1998) Pollination of greenhouse tomatoes by the North American Bombus vosnesenskii (Hymenoptera: Apidae), J. Econ. Entomol. 91, 71-75.

Dollin A. (2003) Bumblebees buzzing, Feral Herald 1(4), 1-2.

Doorn A. van, Heringa J. (1986) The ontogeny of a dominance hierarchy in colonies of the bumblebee Bombus terrestris (Hymenoptera, Apidae), Insectes Soc. 33, 3-25.

Duchateau M.J. (1985) Analysis of some methods for rearing bumblebee colonies, Apidologie 16, 225227.

Duchateau M.J. (1996) Is kin conflict expressed in the colony cycle of the bumble bee Bombus terrestris? Proc. XX Int. Congr. Entomol., Firenze, p. 404.

Duchateau M.J., Mariën J. (1995) Sexual biology of haploid and diploid males in the bumble bee Bombus terrestris, Insectes Soc. 42, 255-266.

Duchateau M.J., Hoshiba H., Velthuis H.H.W. (1994) Diploid males in the bumble bee Bombus terrestris, Entomol. Exp. Appl. 71, 263-269.

Duchateau M.J., Velthuis H.H.W., Boomsma J.J. (2004) Sex ratio variation in the bumblebee Bombus terrestris, Behav. Ecol. 15, 71-82.

Duvoisin N., Baer B., Schmid-Hempel P. (1999) Sperm transfer and male competition in a bumblebee, Anim. Behav. 58, 743-749.

Duyn P. van (1988) Vruchtzetting tomaat: bijen tot half april op taak berekend, Groenten en Fruit 23 (10 juni), 28-31.

Eijnde J. van den (2000) Bumblebee parasites: Nosema bombi and Locustacarus buchneri, in: Sommeijer M.J., Ruijter A. de (Eds.), Insect pollination in greenhouses, Utrecht University \& Ambrosiushoeve, Utrecht, Hilvarenbeek, pp. 3947.

Eijnde J. van den, Ruijter A. de (2000) Bumblebees from the Canary Islands: mating experiments with
Bombus terrestris L. from The Netherlands, Proc. Exp. Appl. Entomol., N.E.V. Amsterdam 11, 159161.

Eijnde J. van den, Ruijter A. de, Steen J. van der (1991) Method for rearing Bombus terrestris continuously and the production of bumblebee colonies for pollination purposes, Acta Hortic. 288, 154158

Ercan N., Onus A.N. (2003) The effects of bumblebees (Bombus terrestris L.) on fruit quality and yield of pepper (Capsicum annuum L.) grown in an unheated greenhouse, Isr. J. Plant Sci. 51, 275-283.

Erlandsson S. (1979) Bombus canariensis Perez, 1895 n. stat. B. maderensis n. sp. from the Macronesian Islands, Entomol. Scand. 10, 187-192.

Estay P., Wagner A., Escaff M. (2001) Evaluación de Bombus dahlbomii (Guér.) como agente polinazador de flores de tomate (Lycopersicon esculentum (Mill.)), bajo condiciones de invernadero, Agric. Tech. (Chile) 61, 113-119.

Estoup A., Scholl A., Pouvreau A., Solignac M (1995) Monoandry and polyandry in bumble bees (Hymenoptera; Bombinae) as evidenced by highly variable microsatellites, Mol. Ecol. 4, 89-93.

Estoup A., Solignac M., Cornuet J.-M., Goudet J., Scholl A. (1996) Genetic differentiation of continental and island populations of Bombus terrestris (Hymenoptera: Apidae), Mol. Ecol. 5, 19-31.

Fisher R.M., Pomeroy N. (1989a) Incipient colony manipulation, Nosema incidence and colony productivity of the bumble bee Bombus terrestris (Hymenoptera: Apidae), J. Kans. Entomol. Soc. $62,581-589$.

Fisher R.M., Pomeroy N. (1989b) Pollination of greenhouse muskmelons by bumble bees (Hymenoptera: Apidae), J. Econ. Entomol. 82, 1061-1066.

Fiume F., Parisi B. (1994) Fitoregolatori e bombidi nella fruttificazione del pomodoro, Colture Protette 10, 87-93.

Foster R.L. (1992) Nestmate recognition as an inbreeding avoidance mechanism in bumble bees (Hymenoptera: Apidae), J. Kans. Entomol. Soc. $65,238-243$.

Free J.B. (1970) Insect pollination of crops, Academic Press, London, New York.

Free J.B. (1993) Insect pollination of crops, 2nd ed., Academic Press, London, San Diego.

Free J.B., Butler C.G. (1959) Bumblebees, Collins, London.

Fries I., Ruijter A. de, Paxton R.J., Silva A.J. da, Slemenda S.B., Pieniazek N.J. (2001) Molecular characterization of Nosema bombi (Microsporidae: Nosematidae) and a note on its sites of infection in Bombus terrestris (Hymenoptera: Apidae), J. Apic. Res. 40, 91-96.

Frison T.H. (1927) The fertilization and hibernation of queen bumblebees under controlled conditions 
(Bremidae: Hym.), J. Econ. Entomol. 20, 522526.

Fye R.E., Medler J.T. (1954) Field domiciles for bumblebees, J. Econ. Entomol. 47, 672-676.

Gamboa G.J., Foster R.L., Richards K.W. (1987) Intraspecific nest and brood recognition by queens of the bumble bee, Bombus occidentalis (Hymenoptera: Apidae), Can. J. Zool. 65, 28932897.

Génissel A., Aupinel P., Bressac C., Tasei J.-N., Chevrier C. (2002) Influence of pollen origin on performance of Bombus terrestris micro-colonies, Entomol. Exp. Appl. 104, 329-336.

Goka K., Okabe K., Yoneda M., Niwa S. (2001) Bumblebee commercialization will cause worldwide migration of parasitic mites, Mol. Ecol. 10, 2095-2099.

Goodell K., Thomson J.D. (1997) Comparisons of pollen removal and deposition by honey bees and bumblebees visiting apple, Acta Hortic. 437, 103107.

Goulson D. (2003a) Bumblebees, their behaviour and ecology, Oxford University Press, Oxford, New York.

Goulson D. (2003b) Effects of introduced bees on native ecosystems, Annu. Rev. Ecol. Evol. Syst. 34, $1-26$.

Goulson D. (2004) Keeping bees in their place: impacts of bees outside their native range, Bee World $85,45-46$.

Gretenkord C., Drescher W. (1997) Successful colony foundation and development of experimentally hibernated Bombus terrestris queens depending on different starting methods, Acta Hortic. 437, 271276.

Griffin R.P., MacFarlane R.P., Ende H.J. van den (1991) Rearing and domestication of long tongued bumble bees in New Zealand, Acta Hortic. 288, 149-153.

Griffiths D. (2004) A critical study on the introduction onto mainland Australia of the bumblebee Bombus terrestris for the commercial pollination of protected tomato and other crops, Practical Hydroponics \& Greenhouses, July/August 2004, 42-59.

Griffiths D., Robberts E.J. (1996) Bumble bees as pollinators of glasshouse crops, in: Matheson A. (Ed.), Bumble bees for pleasure and profit, IBRA, Cardiff, pp. 33-39.

Hagen E. von (1986) Hummeln bestimmen, ansiedeln, vermehren, schützen, Neumann-Neudamm, Melsungen.

Hannan A., Maeta Y., Hoshikawa K. (1997) Colony development of two species of Japanese bumblebees Bombus (Bombus) ignitus and Bombus (Bombus) hypocrita reared under artificial condi- tion (Hymenoptera, Apidae), Jpn J. Entomol. 65, 343-354.

Hasselrot T.B. (1952) A new method for starting bumblebee colonies, Agron. J. 44, 218-219.

Hasselrot T.B. (1960) Studies on Swedish bumblebees (genus Bombus Latr.): their domestication and biology, Opusc. Entomol. Suppl. 17, 1-192.

Heard T.A. (1999) The role of stingless bees in crop pollination, Annu. Rev. Entomol. 44, 183-206.

Heemert C. van, Ruijter A. de, Eijnde J. van den, Steen J. van der (1990) Year-round production of bumble bee colonies for crop pollination, Bee World 71, 54-56.

Heinrich B. (1974) Pheromone induced brooding behaviour in Bombus vosnesenskii and B. edwardsii (Hymenoptera: Bombidae), J. Kansas Entomol. Soc. 47, 396-404.

Heinrich B. (1979) Bumblebee economics, Harvard University Press, Cambridge (Ma), London.

Hergstrom K., Buttermore R., Seeman O., McCorkell B. (2002) Environmental research on the impact of bumblebees in Australia and facilitation of national communication for/against further introductions, Horticulture Australia Project No: VG99033, The Tasmanian Museum and Art Gallery.

Higo H.A., Rice N.D., Winston M.L., Lewis B. (2004) Honey bee (Hymenoptera: Apidae) distribution and potential for supplementary pollination in commercial tomato greenhouses during winter, J. Econ. Entomol. 97, 163-170.

Hingston A.B., McQuillan P.B. (1998a) Does the recently introduced bumblebee Bombus terrestris (Apidae) threaten Australian ecosystems? Aust. J. Ecol. 23, 539-549.

Hingston A.B., McQuillan P.B. (1998b) Nectar robbing in Epacris impressa (Epacridaceae) by the recently introduced bumblebee Bombus terrestris (Apidae) in Tasmania, The Victorian Naturalist 115, 116-119.

Hingston A.B., McQuillan P.B. (1999) Displacement of Tasmanian native megachilid bees by the recently introduced bumblebee Bombus terrestris (Linnaeus, 1758) (Hymenoptera: Apidae), Aust. J. Zool. 47, 59-65.

Hingston A.B., Marsden-Smedley J., Driscoll D.A., Corbett S., Fenton J., Anderson R., Plowman C., Mowling F., Jenkin M., Matsui K., Bonham K.J., Ilowski M., McQuillan P.B., Yaxley B., Reid T., Storey D., Poole L., Mallick S.A., Fitzgerald N., Kirkpatrick J.B., Febey J., Harwood A.G., Michaels K.F., Russell M.J., Black P.G., Emmerson L., Visoiu M., Morgan J., Breen S., Gates S., Bantich M.N., Desmarchelier J.M. (2002) Extent of invasion of Tasmanian native vegetation by the exotic bumblebee Bombus terrestris (Apoidea: Apidae), Aust. Ecol. 27, 162172. 
Hobbs G.A. (1967a) Obtaining and protecting red-clover pollinating species of Bombus (Hymenoptera: Apidae), Can. Entomol. 99, 943-951.

Hobbs G.A. (1967b) Ecology of species of Bombus (Hymenoptera: Apidae) in Southern Alberta, VI. Subgenus Pyrobombus, Can. Entomol. 99, 12711292.

Hobbs G.A., Virostek J.F., Nummi W.O. (1960) Establishment of Bombus spp. (Hymenoptera: Apidae) in artificial domiciles in southern Alberta, Can. Entomol. 92, 868-872.

Hobbs G.A., Nummi W.O., Virostek J.F. (1961) Foodgathering behaviour of honey, bumble, and leafcutting bees (Hymenoptera: Apoidea) in Alberta, Can. Entomol. 93, 409-419.

Hobbs G.A., Nummi W.O., Virostek J.F. (1962) Managing colonies of bumble bees (Hymenoptera: Apidae) for pollination purposes, Can. Entomol. 94, 1121-1132.

Hogendoorn K. (2004) On promoting solitary bee species for use as crop pollinators in greenhouses, in: Freitas B.M., Pereira J.O.P. (Eds.), Solitary bees: conservation, rearing and management for pollination, Imprensa Universitária, Fortaleza, Brazil, pp. 213-221.

Hogendoorn K., Steen Z., Schwarz M.P. (2000) Native Australian carpenter bees as a potential alternative to introducing bumblebees for tomato pollination in greenhouses, J. Apic. Res. 39, 67-74.

Hogendoorn K., Gross C.L., Sedgley M., Keller M.A. (2006) Increased tomato yield through pollination by native Australian blue-banded bees (Amegilla chlorocyanea Cockerell), J. Econ. Entomol., in press.

Holm S.N. (1960) Experiments on the domestication of bumblebees (Bombus Latr.) in particular B. lapidarius L. and B. terrestris L., Royal Veterinary and Agricultural College, Copenhagen, Yearbook 1960, pp. 1-19.

Holm S.N. (1966a) The utilization and management of bumble bees for red clover and alfalfa seed production, Annu. Rev. Entomol. 11, 155-182.

Holm S.N. (1966b) Problems of the domestication of bumble bees, Bee World 47 (Supplement), 179186.

Honk C.G.J. van, Velthuis H.H.W., Röseler P.-F. (1978) A sex pheromone from the mandibular glands in bumblebee queens, Experientia 34, 838839.

Hopkins I. (1914) History of the humble-bee in New Zealand: its introduction and results, N. Z. Dept. Agric. Indus. Comm. 46, 1-29.

Horber E. (1961) Beitrag zur Domestikation der Hummeln, Vjschr. naturf. Ges. Zürich 106, 424447.

Hughes M.J. (1996) Commercial rearing of bumble bees, in: Matheson A. (Ed.), Bumble bees for pleasure and profit, IBRA, Cardiff, pp. 40-47.
Jackson A. (1993) Natural route to pollination, Grower (March 4), 25-26.

Javorek S.K., MacKenzie K.E., Vander Kloet S.P. (2002) Comparative pollination effectiveness among bees (Hymenoptera: Apoidea) on lowbush blueberry (Ericaceae: Vaccinium angustifolium), Ann. Entomol. Soc. Am. 95, 345-351.

Jonghe R. de (1986) Crossing experiments with Bombus terrestris terrestris (Linnaeus, 1758) and Bombus terrestris xanthopus Kriechbaumer, 1870 and some notes on diapause and nosemose (Hymenoptera: Apidae), Phegea 14, 19-23.

Jordan R. (1936) Ein Weg zur zwangsläufigen Nestgründung überwinterter Bombusweibchen an einem bestimmten Platze, Arch. Bienenkd. 17, 39-44.

Katayama E. (1989) Comparative studies on the egglaying habits of some Japanese species of bumblebees (Hymenoptera, Apidae), Jpn J. Entomol., Occasional Publ., No. 2.

Kevan P.G., Straver W.A., Offer M., Laverty T.M. (1991) Pollination of greenhouse tomatoes by bumble bees in Ontario, Proc. Entomol. Soc. Ont. 122, 15-19.

Kraai A. (1958) Bijen en hommels bij het veredelingswerk, Meded. Dir. Tuinb. 21, 291-297.

Kremen C., Williams N.M., Thorp R.W. (2002) Crop pollination from native bees at risk from agricultural intensifications, Proc. Natl Acad. Sci. (USA) 99, 16812-16816.

Krüger E. (1958) Phaenoanalytische Studien an einigen Arten der Untergattung Terrestribombus O. Vogt (Hymenoptera: Bombiidae). III. Teil, Tijdschr. v. Entomol. 101, 283-344.

Kwon Y.J., Saeed S. (2003) Effect of temperature on the foraging activity of Bombus terrestris L. (Hymenoptera: Apidae) on greenhouse hot pepper (Capsicum annuum L.), Appl. Entomol. Zool. 38, 275-280.

Kwon Y.J., Saeed S., Duchateau M.J. (2003a) Stimulation of colony initiation and colony development in Bombus terrestris by adding a male pupa: the influence of age and orientation, Apidologie 34, 429-437.

Kwon Y.J., Saeed S., Duchateau M.J. (2003b) Control of Plodia interpunctella (Lepidoptera: Pyralidae), a pest in Bombus terrestris (Hymenoptera: Apidae) colonies, Can. Entomol. 135, 893-902.

Lee M.-Y., Mah Y.-I., Chang Y.-D., Park I.-H. (1998) Artificial pollination on tomato in the greenhouse by Bombus terrestris, Korean J. Apic. 13, 69-72 (in Korean, with English tables and summary).

Lenteren J.C. van, Woets J. (1988) Biological and integrated pest control in greenhouses, Annu. Rev. Entomol. 33, 239-269.

Lieten F. (1993) Misvormde vruchten door overbevlieging, Groenten en Fruit / Vollegrondsgroenten 14 (9 april), 11. 
MacFarlane R.P., Donovan B.J. (1989) Melittobia spp. as parasitoids of bumble and lucerne leafcutting bees and their control in New Zealand, Proc. 42nd N.Z. Weed and Pest Control Conf., pp. 274-277.

MacFarlane R.P., Patten K.D., Royce L.A., Wyatt B.K.W., Mayer D.F. (1994a) Management potential of sixteen North American bumble bee species, Melanderia 50, 1-12.

MacFarlane R.P., Patten K.D., Mayer D.F., Shanks C.H. (1994b) Evaluation of commercial bumble bee colonies for cranberry pollination, Melanderia 50, 13-19.

MacFarlane R.P., Lipa J.J., Liu H.J. (1995) Bumble bee pathogens and internal enemies, Bee World 76, 130-148.

MacKenzie K.E. (1994) The foraging behaviour of honey bees (Apis mellifera L) and bumble bees (Bombus spp.) on cranberry (Vaccinium macrocarpon Ait), Apidologie 25, 375-383.

Maeta Y. (1990) Utilisation of wild bees, Farming Japan 24(6), 18-24.

Mah Y.-I., Lee M.-Y., Bilinski M. (2001) Some characteristics of Korean indigenous bumblebee species (Hymenoptera; Bombus spp.) under laboratory conditions, Acta Hortic. 561, 287-291.

Matsumura C., Yokoyama J., Washitani I. (2004) Invasion status and potential ecological impacts of an invasive alien bumblebee, Bombus terrrestris L. (Hymenoptera: Apidae) naturalized in Southern Hokkaido, Japan, Global Environ. Res. 8, 51-66.

Maurizio A. (1958) Einfluss der Trocknungsmethode auf die biologische Wirksamkeit des Pollens für Bienen, Z. Bienenforsch. 4, 59-62.

McIvor C., Malone L.A. (1995) Nosema bombi, a microsporidian pathogen of the bumble bee Bombus terrestris (L.), N. Z. J. Zool. 22, 25-31.

Medler J.T. (1957) Bumblebee ecology in relation to pollination of alfalfa and red clover, Insectes Soc. 4, 245-252.

Meisels S., Chiasson H. (1997) Effectiveness of Bombus impatiens $\mathrm{Cr}$. as pollinators of greenhouse sweet peppers (Capsicum annuиm L.), Acta Hortic. 437, 425-429.

Michener C.D. (2000) The bees of the world, John Hopkins, Baltimore, London.

Milliron H.E. (1967) A successful method for artificially hibernating Megabombus F. fervidus, and notes on a related species (Hymenoptera: Apidae; Bombinae), Can. Entomol. 99, 1321-1332.

Minderhoud A. (1950) Het gebruik van bijen en hommels voor bestuiving in afgesloten ruimten, Meded. Dir. Tuinb. 17, 32-39.

Molina Herrera A., Garcia Espinosa E. (1992) Tomate, polinización, Research Report C.I.D.H., La Mojonera, Almería, Spain.

Morandin L.A., Laverty T.M., Kevan P.G. (2001a) Effect of bumble bee (Hymenoptera: Apidae) pol- lination intensity on the quality of greenhouses tomatoes, J. Econ. Entomol. 94, 172-179.

Morandin L.A., Laverty T.M., Kevan P.G. (2001b) Bumble bee (Hymenoptera: Apidae) activity and pollination levels in commercial tomato greenhouses, J. Econ. Entomol. 94, 462-467.

Ono M. (1997) Ecological implications of introduced Bombus terrestris, and significance of domestication of Japanese native bumblebees (Bombus spp.), Proc. Int. Workshop on Biological Invasions of Ecosystem by Pests and Beneficial Organisms, Tsukuba, Japan, pp. 244-252.

Ono M., Mitsuhata M., Sasaki M. (1994) Use of introduced Bombus terrestris worker helpers for rapid development of Japanese native $B$. hypocrita colonies (Hymenoptera, Apidae), Appl. Entomol. Zool. 29, 413-419.

Orlowski M., Grzeszczuk M. (2003) Use of bumble bees for pollination of cherry tomato produced in unheated polyethylene tunnel, Vegetable Crops Res. Bull. 59, 75-82.

Ornosa C. (1995) Una nota de atención sobre la introducción artificial de subespecies foráneas de abejorros polinizadores en la Península Ibérica (Hymenoptera: Apidae, Bombinae), Boln. Asoc. Esp. Entomol. 20, 259-260.

Özbek H. (1993) Decline in Bombus terrestris (L) populations in Turkey, Melissa 6, 7-8.

Paini D.R. (2004) Impact of the introduced honey bee (Apis mellifera) (Hymenoptera: Apidae) on native bees: a review, Aust. Ecol. 29, 399-407.

Parker F.D., Batra S.W., Tepedino V.J. (1987) New pollinators for our crops, Agric. Zool. Rev. 2, 279304.

Paxton R.J., Thorén P.A., Estoup A., Tengö J. (2001) Queen-worker conflict over male production and the sex ratio in a facultative polyandrous bumblebee, Bombus hypnorum: the consequences of nest usurpation, Mol. Ecol. 10, 2489-2498.

Paydas S., Eti S., Kaftanoglu O., Yasa E., Derin K. (2000a) Effects of pollination of strawberries grown in plastic greenhouses by honeybees and bumblebees on the yield and quality of the fruits, Acta Hortic. 513, 443-451.

Paydas S., Eti S., Sevinc S., Yasa E., Derin K., Kaska N., Kaftanoglu O. (2000b) Effects of different pollinators to the yield and quality of strawberries, Acta Hortic. 522, 209-215.

Plowright R.C., Jay S.C. (1966) Rearing bumble bee colonies in captivity, J. Apic. Res. 5, 155-165.

Plowright R.C., Laverty T.M. (1987) Bumble bees and crop pollination in Ontario, Proc. Entomol. Soc. Ont. 118, 155-160.

Pomeroy N., Fisher R.M. (2002) Pollination of kiwifruit (Actinidia deliciosa) by bumble bees (Bombus terrestris): effects of bee density and patterns of flower visitation, N. Z. Entomol. 25, 4149. 
Pomeroy N., Plowright R.C. (1980) Maintenance of bumble bee colonies in observation hives (Hymenoptera: Apidae), Can. Entomol. 112, 321326.

Porporato M., Pinna M., Manino A., Marletto F. (1995) Bombus terrestris (L.) e Apis mellifera L. nell'impollinazione del peperone in coltura protetta, Apicolt. Mod. 86, 99-112.

Pouvreau A. (1963) Observations sur l'accouplement de Bombus hypnorum L. (Hyménoptère, Apidae) en serre, Insectes Soc. 10, 111-118.

Pouvreau A. (1965) Sur une méthode d'élevage des bourdons (Bombus Latr.) à partir de reines capturées dans la nature, Ann. Abeille 8, 147-159.

Pouvreau A. (1970) Données écologiques sur l'hibernation contrôlée des reines de bourdons (Hymenoptera, Apoidea, Bombinae, Bombus Latr.), Apidologie 1, 73-95.

Pouvreau A. (1973) Les ennemis des bourdons. I Étude d'une zoocénose : le nid de bourdons, Apidologie 4, 103-148.

Pouvreau A. (1974) Les ennemis des bourdons. II Organismes affectant les adultes, Apidologie 5, 39-81.

Pouvreau A. (1984) Biologie et écologie des bourdons, in: Pesson P., Louveaux J. (Eds.), Pollinisation et productions végétales, INRA, Paris, pp. 595-630.

Pouvreau A. (2004) Les insectes pollinisateurs, Delachaux et Niestlé.

Pressman E., Shaked R., Rosenfeld K., Hefetz A. (1999) A comparative study of the efficiency of bumble bees and an electric bee in pollinating unheated greenhouse tomatoes, J. Hortic. Sci. Biotech. 74, 101-104.

Prys-Jones O.E., Corbet S.A. (1991) Bumblebees, Richmond Publishing, Slough, England.

Ptacek V. (1985) Testing three methods of bumble bee rearing, Sb. Ved. Prac. VSUP Troubsko 9, 59-67 (in Czech, with English summary).

Ptacek V. (1991) Trials to rear bumble bees, Acta Hortic. 288, 144-148.

Ptacek V. (2000) Obtaining and overwintering young bumble bee (Hymenoptera, Bombinae) queens, in: Sommeijer M.J., Ruijter A. de (Eds.), Insect pollination in greenhouses, Utrecht University \& Ambrosiushoeve, Utrecht, Hilvarenbeek, pp. 5557.

Ptacek V. (2001) Some biological aspects of bumble bee (Bombus, Hymenoptera) management, Acta Hortic. 561, 279-286.

Rasmont P. (1984) Les bourdons du genre Bombus Latreille sensu stricto en Europe Occidentale et Centrale, Spixiana 7, 135-160.

Ravestijn W. van, Bruijn J. de (1991) Belang bestuiving door insekt blijft onduidelijk, Groenten en Fruit 51 (13 december), 18-19.
Ravestijn W. van, Kraemer C. (1991) Hommel doet het goed op mini watermeloen, Groenten en Fruit 46 (15 november), 18-19.

Ravestijn W. van, Nederpel L. (1988) Trostrillers in België aan de kant: hommels doen het werk, Groenten en Fruit 6 (12 februari), 38-41.

Ravestijn W. van, Sande J. van der (1991) Use of bumblebees for the pollination of glasshouse tomatoes, Acta Hortic. 288, 204-212.

Regali A., Rasmont P. (1995) Nouvelles méthodes de test pour l'évaluation du régime alimentaire chez des colonies orphelines de Bombus terrestris (L) (Hymenoptera, Apidae), Apidologie 26, 273-281.

Reuter K., Schwammberger K.-H., Hofmann D.K. (1994) Volksentwicklung und Sammelverhalten von Bombus pascuorum [Scopoli], (Hymenoptera, Apidae), Z. Ang. Zool. 80, 261-277.

Ribeiro M.F., Duchateau M.J., Velthuis H.H.W. (1996) Comparison of the effects of two kinds of commercially available pollen on colony development and queen production in the bumble bee Bombus terrestris L (Hymenoptera, Apidae), Apidologie 27, 133-144.

Richards O.W. (1968) The subgeneric divisions of the genus Bombus Latreille (Hymenoptera: Apidae), Bull. Br. Mus. (Nat. Hist.) Entomol. 22, 209-276.

Röseler P.-F. (1973) Die Anzahl der Spermien im Receptaculum seminis von Hummelköniginnen (Hym., Apoidea, Bombinae), Apidologie 4, 267274.

Röseler P.-F. (1977) Rearing bumblebee colonies, Proc. 8th Int. Congr. IUSSI, Wageningen, p. 312.

Röseler P.-F. (1979) Hummelzucht für den Erwerbsobstbau? Erwerbsobstbau 21, 177-178.

Röseler P.-F. (1985) A technique for year-round rearing of Bombus terrestris (Apidae, Bombini) colonies in captivity, Apidologie 16, 165-170.

Roulston T.H., Cane J.H. (2000) Pollen nutritional content and digestibility for animals, in: Dafni A., Hesse M., Pacini E. (Eds.), Pollen and pollination, Springer-Verlag, Wien, pp. 187-209.

Ruijter A. de, Bruijn J. de (1989) Honingbijen kunnen tot half april trillen bij tomaat vervangen, Groenten en Fruit 20 (19 mei), 36.

Ruijter A. de, Eijnde J. van den, Steen J. van der (1997) Krankheiten und Schädlinge bei der Hummelzucht, Apidologie 28, 222-225.

Ruz L., Herrera R. (2001) Preliminary observations on foraging activities of Bombus dahlbomii and Bombus terrestris (Hym.: Apidae) on native and non-native vegetation in Chile, Acta Hortic. 561, 165-169.

Sabara H.A., Winston M.L. (2003) Managing honey bees (Hymenoptera: Apidae) for greenhouse tomato pollination, J. Econ. Entomol. 96, 547554.

Sabara H.A., Gillespie D.R., Elle E., Winston M.L. (2004) Influence of brood, vent screening, and time of year on honey bee (Hymenoptera: Apidae) 
pollination and fruit quality of greenhouse tomatoes, J. Econ. Entomol. 97, 727-734.

Sakagami S.F. (1966) Techniques for the observation of the behavior and social organization of stingless bees by using a special hive, Pap. Avulso Depto. Zool. S. Paulo 19, 151-162.

Sakagami S.F. (1976) Specific differences in the bionomic characters of bumblebees. A comparative review, J. Fac. Sci. Hokkaido Univ., Ser. VI, Zool. 20, 390-447.

Sampson B.J., Spiers J.M. (2002) Evaluating bumblebees as pollinators of 'Misty' southern highbush blueberry growing inside plastic tunnels, Acta Hortic. 574, 53-61.

Sande J. van der (1990) Bumblebees are a good alternative to truss vibration for beefsteak tomatoes, Hortic. Abstr. 60, 506.

Schmid-Hempel P., Loosli R. (1998) A contribution to the knowledge of Nosema infections in bumble bees, Bombus spp., Apidologie 29, 525-535.

Schmid-Hempel R., Schmid-Hempel P. (2000) Female mating frequencies in Bombus spp. from Central Europe, Insectes Soc. 47, 36-41.

Schmidt J.O., Thoenes S.C., Levin M.D. (1987) Survival of honey bees, Apis mellifera (Hymenoptera: Apidae), fed various pollen sources, Ann. Entomol. Soc. Am. 80, 176-183.

Schmidt J.O., Buchmann S.L., Gilliam M. (1989) The nutritional value of Typha latifolia pollen for bees, J. Apic. Res. 28, 155-165.

Semmens T.D., Turner E., Buttermore R. (1993) Bombus terrestris (L.) (Hymenoptera: Apidae) now established in Tasmania, J. Aust. Entomol. Soc. $32,346$.

Shipp J.L., Whitfield G.H., Papadopoulos A.P. (1994) Effectiveness of the bumble bee, Bombus impatiens Cr. (Hymenoptera: Apidae), as pollinator of greenhouse sweet pepper, Sci. Hortic. 57, 29-39.

Skou J.P., Holm S.N., Haas H. (1963) Preliminary investigations on diseases in bumble-bees (Bombus Latr.), Royal Veterinary and Agricultural College, Copenhagen, Yearbook 1963, pp. 27-41.

Sladen F.W.L. (1912) The humble-bee, MacMillan, London.

Sneep J. (1952) Selection and breeding of some Brassica plants, Proc. 13th Int. Hortic. Congr., pp. 422-426.

Stanghellini M.S., Ambrose J.T., Schultheis J.R. (1997) The effects of honey bee and bumble bee pollination on fruit set and abortion of cucumber and watermelon, Am. Bee J. 137, 386-391.

Stanghellini M.S., Ambrose J.T., Schultheis J.R. (1998a) Seed production in watermelon: a comparison between two commercially available pollinators, Hortic. Sci. 33, 28-30.

Stanghellini M.S., Ambrose J.T., Schultheis J.R. (1998b) Using commercial bumble bee colonies as backup pollinators for honey bees to produce cucumbers and watermelon, Hortic. Tech. 8, 590594.

Stanghellini M.S., Ambrose J.T., Schultheis J.R. (2002) Diurnal activity, floral visitation and pollen deposition by honey bees and bumble bees on field-grown cucumber and watermelon, J. Apic. Res. 40, 27-34.

Stanley R.G., Linskens H.F. (1974) Pollen, SpringerVerlag, Berlin.

Steen J. van der (2000) Diseases and parasites relevant to Bombus terrestris L. indoor rearing, in: Sommeijer M.J., Ruijter A. de (Eds.), Insect pollination in greenhouses, Utrecht University \& Ambrosiushoeve, Utrecht, Hilvarenbeek, pp. 3537.

Stout J.C., Goulson D. (2000) Bumble bees in Tasmania: their distribution and potential impact on Australian flora and fauna, Bee World 81, 8086.

Stout J.C., Kells A.R., Goulson D. (2002) Pollination of the invasive exotic shrub Lupinus arboreus (Fabaceae) by introduced bees in Tasmania, Biol. Conserv. 106, 425-434.

Straver W.A., Plowright R.C. (1991) Pollination of greenhouse tomatoes by bumblebees, Greenhouse Canada 11, 10-12.

Stubbs C.S., Drummond F.A. (2001) Bombus impatiens (Hymenoptera: Apidae): an alternative to Apis mellifera (Hymenoptera: Apidae) for lowbush blueberry pollination, J. Econ. Entomol. 94, 609-616.

Tasei J.-N., Aupinel P. (1994) Effect of photoperiodic regimes on the oviposition of artificially overwintered Bombus terrestris L. queens and the production of sexuals, J. Apic. Res. 33, 27-33.

Tasei J.-N., Moinard C., Moreau L., Himpens B., Guyonnaud S. (1998) Relationship between aging, mating and sperm production in captive Bombus terrestris, J. Apic. Res. 37, 107-113.

Thomson J.D., Goodell K. (2001) Pollen removal and deposition by honeybee and bumblebee visitors to apple and almond flowers, J. Appl. Ecol. 38, 1032-1044.

Torchio P.F. (1987) Use of non-honey bee species as pollinators of crops, Proc. Entomol. Soc. Ont. 118, 111-124.

Vecchio M., Ansanelli C., Giovannantonio C. di, Giustiniani L., Graifenberg A. (1996) Bombi ed ormoni alleganti nel pomodoro in serra, Colture Protette 3, 101-105.

Velthuis H.H.W., Cobb L. (1991) Pollination of Primula in a greenhouse using bumblebees, Acta Hortic. 288, 199-203.

Vogt F.D. (1986) Thermoregulation in bumblebee colonies. I. Thermoregulatory versus broodmaintenance behaviors during acute changes in ambient temperature, Physiol. Zool. 59, 55-59. 
Wada T. (1993) Pollination of fruit vegetables and fruit trees by bumblebees in greenhouses, Farming Japan 27, 38-43.

Wael L. de, Greef M. de, Laere O. van (1993) Melittobia acasta and Bombacarus buchneri, dangerous parasites in the in vitro rearing of bumblebees, Apiacta 28, 93-101.

Whidden T.L. (1996) The fidelity of commercially reared colonies of Bombus impatiens Cresson (Hymenoptera: Apidae) to lowbush blueberry in Southern New Brunswick, Can. Entomol. 128, 957-958.

Whitfield J.B., Cameron S.A. (1993) Comparative notes on hymenopteran parasitoids in bumble bee and honey bee colonies (Hymenoptera: Apidae) reared adjacently, Entomol. News 104, 240-248.

Whittington R., Winston M.L. (2003a) Are bumble bee colonies in tomato greenhouses obtaining adequate nutrition? Can. Entomol. 135, 883-892.

Whittington R., Winston M.L. (2003b) Effects of Nosema bombi and its treatment fumagillin on bumble bee (Bombus occidentalis) colonies, J. Invertebr. Pathol. 84, 54-58.

Whittington R., Winston M.L. (2004) Comparison and examination of Bombus occidentalis and Bombus impatiens (Hymenoptera: Apidae) in tomato greenhouses, J. Econ. Entomol. 97, 1384 1389.

Williams P.H. (1998) An annotated checklist of bumble bees with an analysis of patterns of description (Hymenoptera: Apidae, Bombini), Bull. Nat. Hist. Mus. Lond. (Entomol.) 67, 79-152.

Willmer P.G., Bataw A.A.M., Hughes J.P. (1994) The superiority of bumblebees to honeybees as pollinators: insect visits to raspberry flowers, Ecol. Entomol. 19, 271-284.

Yoon H.-J., Mah Y.-I., Lee M.-Y., Park I.-G., Bilinski M. (1999) Ecological characteristics of Bombus ignitus Smith in Korea, Korean J. Appl. Entomol 38, 101-107 (in Korean, with English tables and summary)

Yoon H.-J., Kim S.E., Kim Y.S. (2002) Temperature and humidity favorable for colony development of the indoor-reared bumblebee, Bombus ignitus, Appl. Entomol. Zool. 37, 419-423.

Zapletal F. (1961) Über die Domestikation der Hummeln, Arch. Geflügelzucht Kleintierkd. 10, 256-262. 